\title{
POROZUMIENIE CO DO PODSTAWY PRAWNEJ ŚWIADCZENIA JAKO PRZESŁANKA KONSTRUKCYJNA 'CONDICTIO OB REM'
}

\section{WPROWADZENIE}

Regulacja świadczenia nienależnego w art. $410 \$ 2$ k.c. jest bardzo syntetyczna. W przepisie tym ujęte są znane od ponad dwóch tysięcy lat roszczenia o zwrot nienależnego świadczenia ${ }^{1}$ nazywane $\mathrm{w}$ nauce i orzecznictwie wzorem terminologii prawa rzymskiego kondykcjami². Jedną z tych kondykcji jest condictio causa data causa non secuta, znana także jako condictio ob causam datorum ${ }^{3}$, choć w romanistyce nazywana

1 Początków roszczeń z bezpodstawnego wzbogacenia należy upatrywać w rzymskiej legis actio per condictionem; zob. M. Sовсzу к, Świadczenie w zamierzonym celu, który nie został osiagnięty. Studium z prawa rzymskiego, Toruń 2012, s. 33 i n.

2 Prawo współczesne przejęło rzymskie condictio indebiti, condictio ob rem, condictio sine causa, zaś regulacja świadczenia niegodziwego w art. 412 k.c., mimo przyjęcia jako zasady zupełnie innego rozwiązania, nawiązuje do condictio ob turpem causam. Także początków condictio ob causam finitam można doszukiwać się w prawie rzymskim, choć tej figury condictio kompilatorzy justyniańscy jeszcze nie wyróżnili. Należy jednak pamiętać, że termin condictio w klasycznym prawie rzymskim oznaczał skargę, a zatem był to termin prawa procesowego, natomiast dzisiejsza kondykcja stanowi desygnat roszczenia o charakterze materialnoprawnym.

3 Tak z kolei nazwano relewantny tytuł Kodeksu Justyniana (C. 4,6). 
częściej condictio ob rem ${ }^{4}$. Jej zwięzłe kodeksowe ujęcie „świadczenie jest nienależne [...], jeżeli zamierzony cel świadczenia nie został osiągnięty" stanowi przyczynę problemów interpretacyjnych, sporów doktrynalnych oraz nieporozumień, w tym zwłaszcza nierzadkich w praktyce prób posłużenia się tą kondykcją w sytuacjach, w których nie powinna być w ogóle brana pod uwagę.

Sformułowanie „zamierzony cel świadczenia” odczytywane samo w sobie, w oderwaniu od wykładni orzeczniczej i doktrynalnej, jest bardzo pojemne, co czyni tę kondykcję szczególnie predestynowaną do nieporozumień i błędnych decyzji w wyborze podstawy prawnej żądania w procesie. Działanie ludzkie bowiem z natury rzeczy jest celowe, zatem osoba, która dokonuje przysporzenia majątkowego na rzecz innej osoby, zwykle czymś się kieruje, coś zamierza osiągnąć, a więc przyświeca jej jakiś cel. Gdyby tak szeroko rozumieć „cel świadczenia”, to condictio ob rem można by stosować w bardzo wielu różnorodnych przypadkach. Dość wspomnieć, że dłużnik wykonujący zobowiązanie, na przykład sprzedawca przenoszący własność rzeczy na kupującego, niewątpliwie działa celowo, zatem gdyby nie otrzymał ustalonego w umowie świadczenia wzajemnego, to także mógłby twierdzić, że cel jego świadczenia nie został osiągnięty i żądać zwrotu własnego świadczenia na tej właśnie podstawie. Podobnie dłużnik działający w wykonaniu zobowiązania umownego bez świadomości nieważności umowy także działa celowo, zatem także żądając restytucji świadczenia, mógłby twierdzić, że jego zamierzony cel nie został osiągnięty. Osoba wręczająca drogi prezent urodzinowy znajomemu w nieujawnionej intencji, aby pozyskać jego przyjaźń lub przychylność w jakiejś sprawie, też realizuje pewien cel, więc również może w przyszłości uważać, że cel ten nie został osiągnięty.

4 Nazwa condictio causa data causa non secuta została użyta w tytule Digestów justyniańskich regulującym tę skargę (D. 12,4). W rzymskim prawie klasycznym prawdopodobnie jeszcze nie rozróżniano poszczególnych figur kondykcji i nie nadawano im swoistych nazw. W rozstrzygnięciach jurystów klasycznych dla świadczeń, które kompilatorzy justyniańscy włączyli do tego tytułu, używano sformułowań ob rem i ob causam, dlatego termin condictio ob rem jest częściej używany w romanistyce, zwłaszcza w odniesieniu do prawa klasycznego. 
Każda z tych sytuacji w jakimś sensie stanowi przykład celu, w każdej z nich świadczący niewątpliwie działa intencjonalnie, realizuje jakiś zamiar. Wbrew pozorom jednak żadna $\mathrm{z}$ nich nie zawiera celu świadczenia $\mathrm{w}$ rozumieniu art. $410 \$ 2$ k.c., nie stanowi przypadku zastosowania condictio ob rem ani w prawie polskim, ani też w obcych systemach prawnych, które recypowały tę rzymską skargę. Już choćby na tych przykładach wyraźnie widać potrzebę wypracowania kryteriów pozwalających na zróżnicowanie condictio ob rem z innymi roszczeniami, które potencjalnie mogą przysługiwać zainteresowanemu w danej sytuacji, zwłaszcza z pozostałymi kondykcjami i reżimem odpowiedzialności kontraktowej. Ostatni z przykładów wskazuje zaś na to, że nie każda motywacja stanowi cel świadczenia, lecz pojęcie celu świadczenia powinno być rozumiane wąsko.

Pełna analiza condictio ob rem wymagałaby pracy o randze monografii z uwagi na wielość szczegółowych wątków, które należałoby podjąć, wysoki poziom trudności i liczne kontrowersje i spory doktrynalne, które należałoby choćby syntetycznie przedstawić. W niniejszej pracy odnoszę się do jednej z najtrudniejszych wypracowanych w orzecznictwie i doktrynie jej cech konstrukcyjnych w postaci wymogu zawarcia „porozumienia co do podstawy prawnej świadczenia”, nazywanego także „porozumieniem woli stron”, zwłaszcza jurydycznej natury tego „porozumienia” i jego treści. Czynię to zarazem z perspektywy historyka prawa, a nie cywilisty, próbując ukazać niektóre szczegółowe wątki tej problematyki z perspektywy historycznej, stąd częste odniesienia do prawa rzymskiego i późniejszych przeobrażeń tej kondykcji.

Ogólne uwagi na temat konstrukcji kondykcji ilustruję, choć tylko w minimalnym niezbędnym zakresie, odniesieniami do dwóch w praktyce bardzo istotnych przypadków jej zastosowania - świadczenia spełnianego na rzecz partnera (konkubenta) w celu dalszego utrzymania związku partnerskiego (konkubinatu) ${ }^{5}$ lub jego sformalizowania przez

5 Nie wdaję się w tym miejscu w spory terminologiczne, co należy rozumieć przez pojęcie konkubinatu i związku partnerskiego. Z punktu widzenia celu niniejszego opracowania nie ma bowiem znaczenia zwłaszcza to, czy chodzi tu o faktyczne pożycie osób heteroseksualnych, czy tej samej płci. Szerzej do tej kwestii odniosłem się 
zawarcie małżeństwa ${ }^{6}$ i świadczenia spełnianego w oczekiwaniu, że odbiorca świadczenia uczyni świadczącego swym spadkobiercą, na przykład pomoc finansowa, nieodpłatne świadczenie usług, sprawowanie opieki nad krewnym lub budowa domu na jego gruncie w oczekiwaniu, że odbiorca świadczenia ustanowi go swym spadkobiercą?

\section{KRYTyKa CONDiCTIO OB REM W NOWOŻYTNEJ NAUCE PRAWA}

Wspomniane trudności towarzyszą condictio ob rem w zasadzie od chwili, kiedy nadano jej po procesie wielowiekowej ewolucji obecną, nowożytną, konstrukcję dogmatyczną. Za tę chwilę uważam ujęcie jej w toku prac drugiej komisji kodyfikacyjnej w przytaczanym poniżej $\$ 812$ I zd. 2 al. 2 niemieckiego kodeksu cywilnego (BGB). Należy jednak zauważyć, że już w uchwalonym w 1881 r. szwajcarskim prawie zobowiązań uregulowano tę kondykcję, choć w semantycznie innym

w pracy Rozliczenia między stronami związków partnerskich na podstawie przepisów o bezpodstawnym wzbogaceniu, «KPP» 2/2015, s. 381 i n.

6 Jest to przykład zastosowania condictio ob rem wywołujący kontrowersje, a nawet zdecydowany sprzeciw części polskiej doktryny prawa, choć częsty w orzecznictwie. Mój punkt widzenia w tej kwestii przedstawiłem w przywoływanym wyżej artykule Rozliczenia.... Zdecydowanie krytyczne stanowisko wobec tej możliwości przedstawił K. Mularski, [w:] Kodeks cywilny. Komentarz, red. M. Gutowski, «Legalis» 2019, nb 17 i n. do art. 410, oraz K. Golec, Zerwanie nieformalnego związku jako przesłanka zwrotu świadczenia, «Monitor Prawniczy» 10/2018, s. 537 i n. Dla odmiany G. KARAszewski ([w:] Kodeks cywilny. Komentarz, red. J. Ciszewski i P. NAzAruk, «Lex» 2019, uwaga 5 do art. 410) uznał tę kondykcję jako podstawowy, oprócz zniesienia współwłasności, mechanizm rozliczeń między konkubentami. Co interesujące, w niemieckim orzecznictwie jest to przykład wręcz podstawowy, który spotkał się także z przychylnością znacznej części doktryny; zob. szeroko C. Sorge, 'Condictio ob rem' und Rückabwicklung gemeinschaftsbezogener Zuwendungen in nichtehelichen Lebensgemeinschaften, «Juristenzeitung» 13/2011, s. 660 i n.

7 Ten przykład także nie jest wolny od kontrowersji; zob. P. Mostowıк, Bezpodstawne wzbogacenie, [w:] System Prawa Prywatnego, VI: Zobowiązania. Część ogólna, Warszawa 2009, s. 307. 
ujęciu, bez wyraźnego odniesienia do celu świadczenia ${ }^{8}$. Niemiecka koncepcja wpłynęła na treść art. 129 polskiego kodeksu zobowiązań, a później na art. $410 \$ 2$ k.c. Polska doktryna prawa przy wykładni tego przepisu korzystała $z$ dorobku orzecznictwa i nauki niemieckiej ${ }^{9}$, warto więc odnotować oceny tam wyrażane.

Kondykcja ta w doktrynie niemieckiej nazywana jest problematycznym dzieckiem kondykcji wynikających ze świadczenia ${ }^{10}$. Niemal w każdej z prac jej poświęconych podkreśla się dużą trudność w jej dogmatycznym ujęciu, ustaleniu jej znaczenia i zakresu zastosowania oraz zróżnicowaniu z innymi roszczeniami restytucyjnymi i kontraktowymi ${ }^{11}$. Żadne $\mathrm{z}$ roszczeń $\mathrm{z}$ tytułu bezpodstawnego wzbogacenia nie jest tak często błędnie rozumiane i nie prowadzi do tak dużych niepewności co do konstrukcji dogmatycznej i zakresu zastosowania ${ }^{12}$. Także w polskiej doktrynie zauważa się, że jest to kondykcja o najbardziej

8 Zob. art. 62 szwajcarskiego prawa zobowiązań (Das Schweizerische Obligationenrecht) w pierwotnej wersji z 14 czerwca 1881 r., a w obecnie obowiązującej z 30 marca 1911 r., aktualna treść dostępna na stronie http://www.zgbor.ch.

9 Widać to wyraźnie zwłaszcza w fundamentalnej monografii W. SERDY, Świadczenie nienależne, Warszawa 1988, s. 91 i n. Ostatnio bogato z tego dorobku czerpał w swych pracach P. KsıĘżaK, Bezpodstawne wzbogacenie. Art. 405-414 KC. Komentarz, Warszawa 2007, passim.

10 D. Reuter, M. Martinek, Ungerechtfertigte Bereicherung, Tübingen 1983, s. 146.

11 D. Liebs, Bereicherungsanspruch wegen Misserfolgs und Wegfall der Geschäftsgrundlage, «Juristenzeitung» 1978, s. 697-703, s. 697; G. WELKER, Bereicherungsausgleich wegen Zweckverfehlung? Kritisches zu $\$ 812$ Abs. 1 S. 2 2.Alt. BGB. Zugleich ein Beitrag zur Struktur der Leistungskondiktion, Berlin 1974, s. 15 i n.; M. WEBER, Bereicherungsansprüche wegen enttäuschter Erwartung?, „Juristenzeitung” 1989, s. 25; B. KuPISCH, Leistungskondiktion bei Zweckverfehlung - Teil 1, "Juristenzeitung» 1985, s. 101; M. LIEB, [w:] Münchener Kommentar zum Bürgerlichen Gesetzbuch, V, Schuldrecht. Besonderer Teil III, München 2007, s. 1308; C.M. LACHner, Die, condictio ob rem'. Ein Beitrag zu Grundlagen und Anwendungsbereich des $\$ 812$ I 2 2Alt. BGB, Würzburg 1996, s. 1 i n.; A. RöTHel, Die Kondiktion wegen Zweckverfehlung, «Juristische Ausbildung» 12/2013, s. 1246; C. SoRGE, Verpflichtungsfreier Vertrag als schuldrechtlicher Rechtsgrund. Das Rechtsgeschäft der 'condictio ob rem' gemäß $\$ 812$ Abs. 1 S. 1 Alt. 2 BGB jenseits von Erfüllungszwang und Markttausch, Göttingen 2017, s. 279.

12 C.M. LaChner, op. cit., s. 1. 
złożonej konstrukcji prawnej i najtrudniejsza do jurydycznego ujęcia ${ }^{13}$. Już kodyfikatorzy niemieckiego kodeksu cywilnego mieli wątpliwości, czy jej regulacja jest rzeczywiście niezbędna $z$ uwagi na znacznie zawężony w porównaniu z prawem rzymskim zakres zastosowania ${ }^{14}$. Jeszcze przed wejściem w życie BGB podkreślano, że wykładnia relewantnego przepisu kodeksu, tj. $\$ 812$ I zd. 2 al. 2, stanowi zagadkę ${ }^{15}$.

W połowie XX w. z uznaniem części doktryny niemieckiej spotkał się bardzo krytyczny wobec niej pogląd Ernsta v. Caemmerera, według którego jest ona historyczną pozostałością i ciałem obcym w obszarze bezpodstawnego wzbogacenia ${ }^{16}$. Określano ją mianem instytucji prawnej sprzecznej z systemem prawnym, wyznaczając właściwie znikomy zakres zastosowania $^{17}$. Pomimo że obecnie większość nauki niemieckiej i polskiej nie kwestionuje już potrzeby istnienia tej kondykcji ${ }^{18}$ i stosunkowo często staje się ona podstawą rozstrzygnięć sądowych, wciąż pojawiają się głosy krytyczne wobec niej i kwestionujące jej niezbędnośćc ${ }^{19}$.

13 Por. K. Mularski, op. cit., nb 14 do art. 410.

14 Zob. protokoły drugiej komisji kodyfikacyjnej niemieckiego kodeksu cywilnego w publikacji B. Mugdan, Die gesammten Materialen zum Bürgerlichen Gesetzbuch für das Deutsche Reich herausgeben und bearbeitet von B. Mugdan, II: Recht der Schuldverhältnisse, Berlin 1899, s. 1174 i n.

15 G. WelKer, op. cit., s. 15 i n.

16 E. v. Caemmerer, Bereicherung und unerlaubte Handlung, Festschrift für E. Rabel, I: Rechtsvergleichung und Internationales Privatrecht, Tübingen 1954, s. 333 i n. Podobnie zob. H.P. Westermann, Die causa im französischen und deutschen Zivilrecht, Berlin 1967, s. 215.

17 M. WeBer, op. cit., s. 30.

18 Co więcej, niektóre z prac odczytuję jako dysertację w obronie tej condictio, co dotyczy zwłaszcza przywoływanej w przypisach monografii C.M. Lachnera.

19 G. Dannemann, The German Law of Unjustified Enrichment and Restitution. A Comparative Introduction, Oxford 2009, s. 49; P. Mostowiк, Bezpodstawne wzbogacenie, [w:] System..., s. 307 i n. 


\section{SyNTEZA PRZESŁANEK KONSTRUKCYJNYCH CONDICTIO OB REM W WYROKU SĄDU NAJWYŻSZEgo Z 17 STYCZNIA 2002 R., III CKN 1500/00}

Punktem wyjścia do dalszych rozważań jest wyrok Sądu Najwyższego z 17 stycznia 2002 r., III CKN 1500/00²0, bowiem jego uzasadnienie zawiera jeden $\mathrm{z}$ pierwszych $\mathrm{w}$ polskim orzecznictwie $\mathrm{w}$ miarę pełnych opisów przesłanek konstrukcyjnych tej kondykcji. Nadto opis ten jest bardzo często przytaczany w późniejszym orzecznictwie ${ }^{21}$ i doktrynie ${ }^{22}$, jeżeli więc któremukolwiek orzeczeniu miano by nadać przymiot wyznacznika późniejszej linii orzeczniczej ${ }^{23}$, to ten wyrok byłby najlepszym kandydatem.

Jak stwierdził w nim Sąd Najwyższy: „Nieosiągnięcie celu świadczenia (condictio ob rem) nie zachodzi, jeżeli cel, który świadczący miał na względzie, spełniając świadczenie, wynika z istotnych postanowień

20 «OSNC» 11/2002, poz. 140.

21 Wyroki SN: z 21 czerwca 2011 r., I CSK 533/10; 13 października 2011 r., V CSK 483/10; 14 listopada 2013 r., II CSK 104/13; 15 kwietnia 2015 r., IV CSK 456/14; 9 października 2015 r., IV CSK 772/14; 21 kwietnia 2016 r., III CNP 18/15; 15 listopada 2016 r., III CNP 9/16; 13 czerwca 2019 r., V CSK 43/18; wyrok SA w Krakowie z 9 października 2012 r., I ACa 904/12; wyrok SA w Warszawie z 20 lutego 2013 r., I ACa 936/12; wyrok SA w Szczecinie z 24 lipca 2013 r., I ACa 331/13; wyrok SA w Warszawie z 2 października 2013 r., I ACa 354/13; wyrok SA w Krakowie z 15 lipca 2014 r., I ACa 637/14; wyrok SA w Białymstoku z 13 lutego 2014 r., I ACa 695/13; wyrok SA w Białymstoku z 18 marca 2015 r., I ACa 985/14; wyrok SA w Gdańsku z 21 lipca 2016 r., V ACa 970/15.

22 P. KsıĘżAK, Kodeks cywilny. Komentarz, red. K. OsAJdA, «Legalis» 2020, uwaga 89 do art. 410; K. KoŁAKowski, [w:] Kodeks cywilny. Komentarz, red. G. BienieK, «LexisNexis» 2011, nb 4 do art. 410; A. RzeteckA-Gil, Kodeks cywilny. Komentarz. Zobowiązania - część ogólna, «Lex» 2011, uwaga 24 do art. 410; T. SoKoŁowsKI, [w:] Kodeks cywilny. Komentarz, red. A. KIDYBA, «Lex» 2014, uwaga 7 do art. 410; R. TRZAsKowsKI, [w:] Kodeks cywilny. Komentarz, red. J. Gudowski, «LexisNexis» 2013, uwaga 18 do art. 410 .

23 Celowo nie używam w tym kontekście terminu „precedens” przede wszystkim dlatego, że w istocie pogląd Sądu Najwyższego stanowił zgrabny, syntetyczny opis najważniejszych znanych już wcześniej przesłanek kondykcji, nie zawierał zaś elementów zupełnie nowych, nieznanych dotychczas. Najistotniejszy walor tego orzeczenia upatruję właśnie w użytecznej i skondensowanej wypowiedzi, które czyni je atrakcyjnym punktem odniesienia w późniejszych orzeczeniach. 
umowy, zawartej z odbiorcą świadczenia. Ma natomiast miejsce wszędzie tam, gdzie celem świadczenia było otrzymanie zamierzonego ekwiwalentnego świadczenia od odbiorcy, który nie był zobowiązany do jego spełnienia i cel ten nie został osiągnięty. Pamiętać jednak należy, że nie każdy cel, którego realizacji oczekuje świadczący, jest z punktu widzenia condictio ob rem prawnie relewantny, dlatego wymaga się, aby cel świadczenia objęty był porozumieniem woli stron (określanym w doktrynie jako porozumienie co do podstawy prawnej świadczenia). Chodzi o to, aby na podstawie ogólnych zasad wykładni można było stwierdzić istnienie między stronami porozumienia woli, z którego treści wynika, że odbiorca otrzymuje świadczenie tylko ze względu na oczekiwany cel".

Mając na uwadze niezwykle zwięzłą treść art. $410 \$ 2$ k.c., ograniczającą się do bardzo krótkiego sformułowania „zamierzony cel świadczenia nie został osiągnięty”, tak szeroka wypowiedź Sądu Najwyższego prowokuje do pytania, czym uzasadnione są wszystkie przytaczane w niej wymogi zastosowania przedmiotowej kondykcji. Nie wynikają one bowiem bezpośrednio $\mathrm{z}$ treści przepisu, zwłaszcza nie są $\mathrm{w}$ nim werbalnie ujęte. W samej treści przepisu nie ma w szczególności wyraźnego wymogu istnienia jakiegoś porozumienia między świadczącym i odbiorcą świadczenia. Nie wynika z niej wprost, że kondykcja ta nie ma zastosowania w najbardziej typowej i najczęstszej sytuacji, tj. w odniesieniu do umów kreujących zaskarżalne, możliwe do dochodzenia na drodze sądowej, innymi słowy wymuszalne, zobowiązania. Tym bardziej przepis ten nie zawiera żadnej wzmianki, która by chociaż pośrednio sugerowała, że odbiorca świadczenia ma w zamian za nie spełnić uzgodnione w owym porozumieniu świadczenie wzajemne, do którego nie jest jednak prawnie zobowiązany.

Wywód Sądu Najwyższego może wprawiać w zakłopotanie nawet prawnika, jeżeli dotychczas nie wnikał w istotę tej kondykcji. Wynika to przede wszystkim $\mathrm{z}$ faktu, że każde $\mathrm{z}$ tych wymagań powoduje istotne zawężenie zakresu zastosowania kondykcji, które następuje wbrew wspomnianemu wyżej pierwszemu wrażeniu, że przepis ten odnosi się do każdego celu świadczenia, w tym zwłaszcza celu wynikającego z typowej umowy. Tymczasem cytowana wykładnia prowadzi do znacznego 
zawężenia zakresu zastosowania przepisu, ograniczając ten zakres do przypadków rzadkich. Poza tym kategoria „porozumienia”, które tym różni się od umowy, że nie jest źródłem roszczeń (zaskarżalnych zobowiązań), nie jest typowa i nieczęsto spotyka się ją w praktyce. Ze względu na obowiązującą współcześnie zasadę swobody umów umowa spełniająca tylko najbardziej rudymentarne wymagania w postaci zgodności z prawem, dobrymi obyczajami i naturą zobowiązania, jest prawnie wiążąca i zaskarżalna, w tym znaczeniu, że jej wykonania lub odszkodowania za jej niewykonanie można dochodzić na drodze sądowej.

Wydawać by się mogło zatem, że już nie powinno być miejsca na żadną dodatkową, osobliwą kategorię porozumień, które różnią się od umów w najbardziej podstawowym aspekcie, mianowicie przymusowej egzekwowalności (wymuszalności) podjętych uzgodnień. Można postawić pytanie, jaki jest sens wyróżniania porozumień, których wykonanie zależy wyłącznie od dobrej woli stron. W rezultacie osobie niewtajemniczonej kodeksowe ujęcie condictio ob rem nie tylko niemal „nic nie mówi”, lecz wręcz prowadzi do fałszywych wniosków i próby jej zastosowania w stanach faktycznych, w których w ogóle nie powinna być stosowana. Dowodem tego są nierzadkie próby jej zastosowania na gruncie umów ${ }^{24}$.

W kontekście powyższych uwag oczywiste staje się zatem, że pod cytowanym bardzo krótkim sformułowaniem kodeksowym kryje się rozbudowana i skomplikowana koncepcja orzeczniczo-doktrynalna, która wyjaśnia konstrukcję, znaczenie i zakres zastosowania condictio ob rem. Koncepcja ta zakotwiczona jest, tj. znajduje punkt oparcia, w brzmieniu przepisu, jednakże to nie tyle użyte przez ustawodawcę sformułowanie, ile dopiero ona nadaje temu przepisowi właściwe znaczenie, nakazując przywiązać wagę do aspektów explicite w nim niewyartykułowanych. Trudno jest wskazać w kodeksie cywilnym inny przykład przepisu, którego prawidłowe rozumienie aż w tak dużym stopniu zostało wypracowane dopiero w orzecznictwie i doktrynie, i zarazem którego semantyczne ujęcie może być aż tak mylące. Powstaje

24 Zob. stany faktyczne spraw rozstrzygniętych wyrokami SN: z 17 stycznia 2002 r., III CKN 1500/00; 21 czerwca 2011 r., I CKS 533/10; 13 czerwca 2019 r., V CSK 43/18. 
zatem pytanie, na jakich podstawach teoretycznych Sąd Najwyższy wywiódł cytowaną koncepcję, czy jest ona pełna i czy na pewno w każdym elemencie prawidłowa.

Odpowiedź na pytanie o prawidłowe rozumienie condictio ob rem we współczesności i poprawnie wyznaczony zakres jej zastosowania wymaga w mojej ocenie przeprowadzenia dwóch operacji myślowych o zasadniczym znaczeniu. Po pierwsze, prześledzenia procesu powstania i ewolucji condictio ob rem, począwszy od jej korzeni w prawie rzymskim $^{25}$. Po drugie, wskazania kryteriów różnicujących, bowiem rozumienie condictio ob rem zostało w toku tej ewolucji ukształtowane w opozycji do innych roszczeń mających zastosowanie w podobnych sytuacjach, choć pełniących inne funkcje i służących innym celom. Przesłanki konstrukcyjne tej kondykcji były w toku ewolucji prawa w ten sposób kształtowane, aby miała zastosowanie wyłącznie w zakresie nieobjętym innymi regulacjami prawnymi, innymi słowy, aby nie stanowiła konkurencji dla innych roszczeń, tylko je uzupełniała, zatem pełniła funkcję subsydiarną. Proces ten, trwający blisko dwa tysiące lat, prowadził do znacznego ograniczenia zakresu zastosowania condictio ob rem, czyniąc $\mathrm{z}$ niej remedium w istocie ostatniego wyboru, stosowane dopiero wtedy, gdy inne przepisy prawa nie zapewniają należytej ochrony.

Czym zatem uzasadnić przesłankę, że condictio ob rem nie ma zastosowania na gruncie zobowiązań wynikających z umów, lecz tylko w odniesieniu do porozumień co do podstawy prawnej świadczenia nierodzących wiążących prawnie, egzekwowalnych zobowiązań? Wydaje się, że już sam termin „porozumienie”, a nie „umowa”, jest używany w celu podkreślenia odmiennego charakteru podjętych uzgodnień, przede wszystkim pozbawienia ich typowej dla umów ochrony prawnej. Wymóg podjęcia takich uzgodnień obowiązywał już w prawie rzymskim, czego najważniejszym dowodem jest fakt, że pewne niezaskarżalne jeszcze w prawie klasycznym umowy, nazwane później kontraktami

25 Kondykcje, w tym ob rem, uznaje się za oryginalny dorobek myśli jurystów rzymskich, bowiem inne systemy prawne starożytności ich nie znały, a współczesna regulacja prawna świadczenia nienależnego jest zasadniczo na nich oparta. 
nienazwanymi, stanowiły jednak umowy, a zatem były wyrazem zgodnej woli obu stron. Współczesne orzecznictwo unika tu posługiwania się terminologią „zaskarżalna” i „niezaskarżalna” umowa, wychodząc z założenia, że każda umowa spełniająca przytaczane wyżej podstawowe wymogi jest zaskarżalna, tzn. kreuje zobowiązania, z którymi łączy się prawna odpowiedzialność za ich wykonanie. Tymczasem z punktu widzenia historii prawa rozróżnienie zaskarżalnej i niezaskarżalnej umowy jest jak najbardziej naturalne, bowiem nawiązuje do rozróżniania między rzymskim contractus (umową chronioną skargą procesową) i pactum nudum („naga umowa”, pozbawiona ochrony procesowej).

\section{ZAMIERZONY WEDŁUG TREŚCI CZYNNOŚCI PRAWNEJ SKUTEK ŚWIADCZENIA W NIEMIECKIM KODEKSIE CYWILNYM}

$\mathrm{W} \S 812$ I zd. 2 al. 2 BGB uregulowano condictio ob rem następująco: „Kto wskutek świadczenia ze strony drugiego [...] uzyskuje cokolwiek bez podstawy prawnej, obowiązany jest do zwrotu. Obowiązek ten istnieje także wtedy [...], gdy nie nastąpi skutek, jaki według treści czynności prawnej (Rechtsgeschäft) zamierzono osiągnąć (der bezweckte Erfolg) przez świadczenie" 26 .

Na wstępie warto zauważyć, że taką treść przepisu nadano dopiero podczas prac drugiej komisji kodyfikacyjnej $\mathrm{BGB}^{27}$, po odrzuceniu, wskutek krytyki pierwszego projektu regulacji tej kondykcji opartej na koncepcji założenia (Voraussetzung) ${ }^{28}$ wielkiego pandektysty i chyba najwybitniejszego niemieckiego prawnika drugiej połowy XIX w. Bern-

26 „Wer durch die Leistung eines anderen [...] ohne rechtlichen Grund erlangt, ist ihm zur Herausgabe verpflichtet. Diese Verpflichtung besteht auch dann, wenn [...] der mit einer Leistung nach dem Inhalt des Rechtsgeschäfts bezweckte Erfolg nicht eintritt”.

${ }^{27}$ Na temat przebiegu prac nad niemieckim kodeksem cywilnym zob. K. SójKA-ZielińsKa, Wielkie kodyfikacje cywilne. Historia i współczesność, Warszawa 2009, s. 292 i n.

28 Doktryna ta została wyłożona w dwóch pracach: Die Lehre des römischen Rechts von der Voraussetzung, Düsseldorf 1850, i Die Voraussetzung, "Archiv für die civilistische Praxis» 78/1892, s. 161-202. 
harda Windscheida ${ }^{29}$. Ma to znaczenie o tyle, że komisja kodyfikacyjna przekonana do odrzucenia doktryny Windscheida i mająca wątpliwości, czy w ogóle regulować tę kondykcję, przyjęła, prawdopodobnie bez pogłębionej refleksji, cytowaną treść przepisu. Od początku zatem w pracach obu komisji kodyfikacyjnych dostrzegano duże trudności w poprawnym ujęciu condictio ob rem, które sprowadziły się w pewnym momencie do dyskusji nad koncepcją „założenia”30, a gdy ta została ostatecznie odrzucona, w jej miejsce zaproponowano cytowaną wyżej treść. Zarówno „założenie” Windscheida, jak i aktualna treść przepisu inspirowane są źródłami prawa rzymskiego, jednakże interpretowanymi w sposób częsty w ówczesnej pandektystyce w duchu twórczej wykładni myśli jurystów rzymskich i tym samym traktowanymi bardziej właśnie jako źródło inspiracji pomysłów na treść projektowanych przepisów prawa $^{31}$. Już od chwili powstania treść przytaczanego przepisu stanowiła w znacznym stopniu innowację, niekoniecznie przemyślaną, dość niejasną i przez to podatną na nieporozumienia i kontrowersje.

Cytowany przepis zawiera termin „zamierzony skutek” (der bezweckte Erfolg), w przeciwieństwie do art. $410 \$ 2$ k.c. i wcześniej art. 129 k.z., w których użyto terminu „zamierzony cel świadczenia”. Niemniej niemiecki termin Erfolg nie jest jednoznaczny i może być przetłumaczony w tym kontekście jako skutek, wynik lub rezultat, które co do zasady oznaczają to samo, można ich zatem używać zamiennie ${ }^{32}$. Nawiązują

29 Życiorys tego wybitnego prawnika stał się przedmiotem opracowania R. WoJCiechowskiego, Bernhard Windscheid (1817-1892), «Kwartalnik Prawa Prywatnego» 18/2009, s. 593-619.

30 Najsurowszym krytykiem koncepcji Windscheida okazał się wybitny romanista O. Lenel, Die Lehre von der Voraussetzung (in Hinblick auf den Entwurf eines bürgerlichen Gesetzbuches), «Archiv für die civilistische Praxis» 74/1889, s. 213-239; IDEM, Nochmals die Lehre von der Voraussetzung, «Archiv für die civilistische Praxis» 79/1892, s. 49-107.

31 Koncepcja założenia Windscheida stanowi w bardzo dużym stopniu taką twórczą wykładnię źródeł rzymskich. Moim zdaniem jest to wręcz imponujący przykład wywodzenia z prawa rzymskiego koncepcji w zasadzie nowych, dostosowanych do realiów społecznych i gospodarczych, w których je proponowano.

32 W przywoływanych w niniejszym artykule pracach doktryny niemieckiej nie doszukałem się prób odróżnienia celu od skutku lub wyniku świadczenia, przeciwnie, 
one do rzymskiej datio ob rem i datio ob causam i podobnie jak terminy rzymskie są pojemne i trudno definiowalne, choć wyrażają celowość działania świadczącego.

W treści $\$ 812$ I zd. 2 al. 2 BGB zawarty jest termin, którego brakuje w art. $410 \$ 2$ k.c. - Rechtsgeschäft oznaczający czynność prawną ${ }^{33}$. Jego użycie stanowi jedną z przyczyn fałszywych interpretacji, co często podkreślane jest w doktrynie ${ }^{34}$. Użycie to może bowiem sugerować, że zamierzony skutek/rezultat świadczenia powinien, a przynajmniej może wynikać z typowej czynności prawnej, zwłaszcza z umowy. Skoro jednak condictio nie może być stosowana na gruncie egzekwowalnych zobowiązań umownych, o czym niżej, to termin Rechtsgeschäft musi być rozumiany swoiście, inaczej niż w swym zasadniczym znaczeniu. Z tego względu używa się terminu „faktyczne uzgodnienie” (tatsächliche Einigung $^{35}$, tatsächliche Willensübereinstimmung ${ }^{36}$ ). Termin ten uwydatnia bardziej faktyczny niż prawny wymiar uzgodnień stron i różnicę znaczeniową $\mathrm{w}$ porównaniu $\mathrm{z}$ zasadniczym rozumieniem pojęcia Rechtsgeschäft.

Niektórzy doszukują się tu niedoskonałego kontraktu synalagmatycznego, stawiając tezę, że to jednak ciągle kontrakt ${ }^{37}$. Podej-

termin „cel” (Zweck) jest często używany w znaczeniu, w jakim verba legis użyty został termin „skutek” (Erfolg). Przywoływany w przypisach artykuł A. Röthel nosi znamienny tytuł Die Kondiktion wegen Zweckverfehlung. Alfred Ohanowicz pisał w tym kontekście o wyniku świadczenia (A. OHAnowicz, Niesłuszne wzbogacenie, [w:] A. OHAnowicz, Wybór prac, red. A. Gulczyński, Warszawa 2007, s. 836); z kolei W. Serda przez pojęcie Erfolg rozumie cel lub wynik świadczenia (W. SERDA, op. cit., s. 91).

33 Termin ten w znaczeniu czynności prawnej został użyty w kodeksie wiele razy, w szczególności w rozdziale trzecim księgi pierwszej „Czynności prawne” (\$ 104 i n. $\mathrm{BGB})$.

34 C.M. LaChner, op. cit., s. 25; M. Lieb, op. cit., s. 1310; C. Sorge, Verpflichtungsfreier Vertrag..., s. 283 i n.

35 C.M. Lachner, op. cit., s. 27; O. MüHL, W. Hadding, Soergel Kommentar zum Bürgerlichen Gesetzbuch, Band 5/1, Schuldrecht IV/1, Stuttgart 2007, s. 114.

36 Wyroki Federalnego Sądu Najwyższego (BGH): z 28 września 1961 r., VII ZR 22/60; z 29 listopada 1965 r., VII ZR 214/63; z 10 listopada 2003 r., II ZR 250/01; z 25 listopada 2009 r., XII ZR 92/06; z 9 lipca 2008 r., XII ZR 179/05; z 22 marca 2013 r., V ZR 28/12; z 17 lipca 2013 r., IV ZR 309/12; A. RöTHEL, op. cit., s. 147.

37 K. Larenz, C.W. Canaris, Lehrbuch des Schuldrechts, München 1994, s. 152. 
mowane są też próby uzasadnienia szerokiego rozumienia terminu Vertrag, obejmującego także umowy, z których nie wynika zaskarżalne zobowiązanie $^{38}$.

Z kolei w doktrynie polskiej Paweł Księżak stwierdza stanowczo, że porozumienie to nie jest umową, bo jeśli nią będzie, problem przesunie się na płaszczyznę kontraktową ${ }^{39}$. Polski Sąd Najwyższy w przywoływanym wyroku z 17 stycznia 2002 r., III CKN 1500/00 uznał, że „porozumienie co do podstawy prawnej świadczenia nie jest uważane za czynność prawną, zwłaszcza zdatną do wysuwania roszczeń”, jednakże w kilku późniejszych orzeczeniach nie zajął wyraźnego stanowiska, czy to porozumienie w ogóle jest czynnością prawną, poprzestając na stwierdzeniu, że nie jest czynnością prawną, która stanowiłaby źródło roszczeń spełniającego świadczenie ${ }^{40}$.

Kwalifikacja prawna porozumienia zależy zatem od rozumienia samego pojęcia umowy, bowiem jeżeli przez umowę rozumieć także takie zgodne oświadczania woli stron, z których nie wynikają roszczenia o wykonanie ustalonych w nich zobowiązań, to porozumienie stanowiłoby umowę.

Wydaje się, że z uwagi na supremację zasady swobody umów obecnie tak szerokie rozumienie umowy budziłoby spore wątpliwości i nie spotkałoby się z powszechną aprobatą, choć dla historyka prawa nie byłoby niczym osobliwym. W tym też upatruję przyczyn konsekwentnego posługiwania się terminem „porozumienie” lub „faktyczne uzgodnienie”, a nie umowa. Podkreślam także, że kwestia ta jest interesująca na płaszczyźnie teoretycznej, natomiast w praktycznym użyciu kondykcji podstawowe znaczenie ma fakt, że świadczącemu nie przysługuje żadne roszczenie o świadczenie wzajemne lub o realizację celu

38 Rozważania w tej kwestii podjął w bardzo obszernej i wnikliwej monografii C. Sorge, Verpflichtungsfreier Vertrag..., passim.

39 P. KsIĘŻAK, Bezpodstawne wzbogacenie..., s. 193; IDEM, Kodeks cywilny..., uwaga 95 do art. 410.

40 Zob. wyroki SN z: 26 czerwca 2011 r., I CSK 533/10, i z 13 czerwca 2019 r., V CSK $43 / 18$. 
świadczenia w inny sposób ${ }^{41}$. Czy uzgodnienie celu świadczenia należy nazwać umową, czy porozumieniem, jest doniosłe w praktyce chyba jedynie w tym wymiarze, że posłużenie się terminem „umowa”, a nawet szerszym terminem „czynność prawna”, tym bardziej prowadziłoby do jeszcze większych nieporozumień i prób stosowania kondykcji na gruncie umów, z których wynikają roszczenia o ich wykonanie. Stąd też opowiadam się za zachowaniem dotychczasowej odmienności terminologicznej i odróżnianiem przedmiotowego porozumienia od umowy.

Podkreślenia wymaga w tym miejscu, że konieczność odróżnienia porozumienia od umowy wynika z wykładni systemowej, a nie językowej przepisu, bowiem jest to konsekwencja podstawowego założenia, że condictio ob rem nie powinna być stosowana w odniesieniu do umów, z których wynikają roszczenia o ich wykonanie.

\section{Niedopuszczalność Zastosowania CONDictio ob REM W ODNIESIENIU DO UMÓW KREUJĄCYCH ROSZCZENIA ORAZ W ZAKRESIE ZASTOSOWANIA POZOSTAŁYCH KONDYKCJI}

Pogląd o niedopuszczalności zastosowania condictio ob rem $\mathrm{w}$ obszarze umów kreujących zaskarżalne zobowiązania ${ }^{42}$ wynika z wielowiekowej ewolucji systemu kontraktowego zakończonej ostatecznie

${ }^{41}$ Nie istnieje roszczenie o realizację celu świadczenia; zob. C.M. LACHNER, op. cit., s. 31; M. Lieb, op. cit., s. 1311.

42 Jest to pogląd niekwestionowany w nauce; zob. M. LIEB, op. cit., s. 1310; O. MüHL, W. Hadding, op. cit., s. 1142, H. Gramm, [w:] Beck'sche Kurzkommentare, VII Palandt, Bürgerliches Gesetzbuch, München 2004, s. 1191; K. LAREnZ, C.W. CANARIs, op. cit., s. 150; H.J. Wieling, Bereicherungsrecht, Berlin 2013, s. 26; C. SoRGE, Verpflichtungsfreier Vertrag..., s. 284. W orzecznictwie niemieckim zob. wyroki BGH z 12 lipca 1989 r., VIII ZR 286/88, i z 17 czerwca 1992 r., XII ZR 253/90. W doktrynie polskiej: W. SERDA, op. cit., s. 93; E. ŁęTowska, Bezpodstawne wzbogacenie, Warszawa 2000, s. 98; P. Mostowik, Bezpostawne wzbogacenie, [w:] System..., s. 265 i n.; P. Ksı̨̨żAK, Kodeks cywilny..., uwaga 91 do art. 410; W. DuBIs, [w:] Kodeks cywilny. Komentarz, red. E. GnieweK, Warszawa 2016, nb 13 do art. 410. Jednoznacznie przyjęło go także polskie orzecznictwo; zob. tylko ostatnio: wyroki SN z: 16 czerwca 2016 r., V CSK 581/15; z 25 maja 2018 r., I CSK 482/17; z 5 czerwca 2019 r., V CSK 265/18; z 13 czerwca 2019 r., V CSK 43/18. 
uznaniem w osiemnasto- i dziewiętnastowiecznych kodyfikacjach cywilnych zasady swobody umów, paralelnie do zmniejszającego się zakresu użycia i znaczenia tej kondykcji. Otóż w prawie rzymskim obowiązywała zasada nominalizmu kontraktowego stanowiąca przeciwieństwo współczesnej zasady swobody umów. Strona mogła żądać wykonania zobowiązania tylko wtedy, kiedy zawarta przez nią umowa była chroniona przez odpowiednią skargę (actio), wiele zaś umów stanowiło jedynie pactum nudum, tj. umowę nieobjętą taką ochroną ${ }^{43}$. Aż do schyłku epoki rzymskiego prawa klasycznego (III w. n.e.), a być może nawet aż do prawa justyniańskiego (VI w. n.e.), umowy niestanowiące żadnego z uznanych contractus, a przynależne do grupy nazwanej przez średniowiecznych glosatorów kontraktami nienazwanymi (contractus innominatus) ${ }^{44}$, nie były chronione skargą o wykonanie zobowiązania wzajemnego, lecz ta strona, która spełniła swoje świadczenie, licząc na uzgodnione świadczenie wzajemne, mogła za pomocą condictio ob rem żądać jego zwrotu. Tym samym w prawie rzymskim condictio ob rem była stosowana między innymi w odniesieniu do świadczeń spełnionych w wykonaniu niezaskarżalnej umowy ${ }^{45}$, jeżeli druga strona nie zaoferowała świadczenia wzajemnego. Już jednak prawdopodobnie w prawie

${ }^{43}$ Literatura poświęcona zasadzie nominalizmu kontraktowego i jej przełamywaniu w prawie rzymskim jest bardzo bogata, dlatego ograniczam się do wskazania kilku najnowszych prac w języku polskim zawierających dalsze odesłania: A. SzymańskA, Actio civilis in factum - actio praescriptis verbis w responsach Labeona, «Studia Iuridica» 41/2003, s. 293 i n.; M. GoleCKI, Synallagma. Filozoficzne podstawy odpowiedzialności kontraktowej w klasycznym prawie rzymskim, Toruń 2008, passim; M. SовCZy к, Świadczenie..., s. 325 i n.; R. ŚwIRGoŃ-SKoK, Pretorskie pacta conventa servabo jako rzymskie korzenie zasady pacta sunt servanda, [w:] Pacta sunt servanda - nierealny projekt czy gwarancja ładu społecznego, red. E. Kozerska, P. SAdowski, A. SzymańsKi, Kraków 2015, s. 13 i n.

44 Juryści klasyczni ujęli te umowy w schematy do ut des (daję, abyś dał), do ut facias (daję, abyś uczynił), facio ut des (czynię, abyś dał) i facio ut facias (czynię, abyś uczynił); zob. zwłaszcza D. 12,4,16 (Cels. 3 dig.), D. 12,6,52 (Pomp. 17 ad Q. Muc.), D. 12,6,65,4 (Paul. 17 ad Plaut.), D. 19,4,1,4 (Paul. 32 ad ed.), D. 19,5,5pr.-2 (Paul. 5 quaest.).

45 Nie podzielam w tym miejscu twierdzenia W. SERdy (op. cit., s. 90 i n.) że condictio ob rem znajdowała swoje zastosowanie w bezumownej datio ob rem i uzupełniała condictio indebiti w zakresie pozaumownych świadczeń. Autor ten nie odróżnia dostatecznie contractus (umowy zaskarżalnej) od pactum (umowy niezaskarżalnej), 
późnoklasycznym, a na pewno w prawie justyniańskim, umowy niebędące uznanymi kontraktami stopniowo zaczęły być chronione skargą o świadczenie wzajemne (zwłaszcza actio praescriptis verbis), z której mogła skorzystać strona, po tym, jak już spełniła swoje świadczenie ${ }^{46}$. $\mathrm{W}$ rezultacie na pewnym etapie rozwoju prawa rzymskiego zaistniał dualizm ochrony procesowej, gdyż świadczący mógł dokonać wyboru jednej z alternatywnych skarg, kondykcja była więc stosowana pomimo możliwości wyegzekwowania świadczenia wzajemnego. W późniejszym rozwoju prawa, kiedy przełamano zasadę nominalizmu kontraktowego i uznano, że z każdej umowy wynika roszczenie o wykonanie zobowiązania wzajemnego ${ }^{47}$, zauważano, że nie ma potrzeby utrzymania owej konkurencji roszczeń ${ }^{48}$. Osiemnastowieczne kodeksy cywilne nie przewidywały już zastosowania condictio ob rem w obszarze kontraktów, $\mathrm{w}$ to miejsce zachowując rozbudowane przepisy dotyczące odpowiedzialności kontraktowej ${ }^{49}$.

Kodyfikatorzy BGB u schyłku XIX w. nie mogli zatem zawrócić kierunku ewolucji, przywracając condictio ob rem jako alternatywę dla roszczenia o wykonanie zobowiązania wzajemnego. Byłoby to nieracjonalne zwłaszcza na tych obszarach ówczesnej Rzeszy, na których od dawna

dlatego jego uwagi są poprawne przy założeniu, że odnosi condictio ob rem do umów niezaskarżalnych, a nie do świadczeń pozaumownych.

46 D. 18,1,50 (Ulp. 11 ad ed.), D. 19,5,19pr. (Ulp. 31 ad ed.). Proces ten szczegółowo opisuję w monografii Świadczenie..., s. 325 i n.

47 Na temat ewolucji prowadzącej do uznania zasady pacta sunt servanda zob. R. Zimmermann, The Law of Obligations. Roman Foundations of the Civilian Tradition, Cape Town-Wetton-Johannesburg 1990, s. 843; IDEM, Roman-Dutch jurisprudence and its Contribution to European Private Law, «Tulane Law Review» 66.6/1992, s. 1686 i n.; R.A. Momberg Uribe, The effect of change of circumstances on the binding force of contracts, Utrecht 2011, s. 23 i n.; D. MAKIŁŁA, Pacta sunt servanda-grocjuszowski koncept prawnonaturalnego ładu w społeczeństwie, [w:] Pacta sunt servanda - nierealny projekt czy gwarancja ładu społecznego, red. E. Kozerska, P. SAdowski, A. SzymańSKI, Kraków 2015, s. 47 i n.; M. SoвCZy , 'Condictio causa data causa non secuta' and development of the contractual system, «Krakowskie Studia z Historii Państwa i Prawa» 11.2/2018, s. 177-195.

48 M. WEBER, op. cit., s. 27.

49 Zob. zwłaszcza bawarski kodeks cywilny Księcia Maksymiliana III Józefa z 1756 r. (IV $13 \S 7$ ) oraz Landrecht pruski z 1794 r. (I $16 \$ 199$ i n.). 
obowiązywały kodeksy odrzucające tę alternatywę. Co więcej, jako jeden z podstawowych argumentów przeciwko regulacji tej kondykcji w BGB podnoszono niebezpieczeństwo, że będzie ona nadużywana i stosowana na gruncie prawnie wiążących umów ${ }^{50}$. Choć zaś doświadczenie prawa rzymskiego wskazuje na to, że rezygnacja z condictio ob rem w obszarze umów nie jest koniecznością, to jednak brakowało argumentów za przywróceniem tego pola zastosowania kondykcji.

W świetle powyższego ujęcia zamierzony skutek świadczenia może się odnosić co najwyżej do takiego zachowania odbiorcy świadczenia, które w ogóle nie może być przedmiotem zaskarżalnego zobowiązania lub też z jakichś względów odbiorca świadczenia w danym przypadku nie chce zaciągnąć zaskarżalnego zobowiązania, choć jest to teoretycznie możliwe ${ }^{51}$.

Odnosząc te uwagi do wzmiankowanych wyżej przykładów zastosowania omawianej kondykcji, zauważam, że trudno przyjąć, aby strony związków partnerskich mogły zawierać ważną i skuteczną umowę zobowiązującą je do wspólnego pożycia aż do śmierci lub choćby na czas określony i wywodzić z tej umowy odpowiedzialność kontraktową. Taka umowa zbyt mocno ograniczałaby wolność osobistą stron i przez to nie mieściłaby się w zakresie dozwolonym zasadą swobody umów. Poza tym ze względu na osobiste relacje łączące strony nie będą one skłonne do zwłaszcza tak daleko idącej formalizacji podjętych uzgodnień. Skoro strony nie decydują się na zawarcie związku małżeńskiego, to często, choć nie zawsze, oznacza to niechęć do formalizacji łączących je stosunków w jakiejkolwiek sferze.

Jeżeli chodzi natomiast o drugi częsty przykład świadczeń w zamierzonym celu, że odbiorca świadczenia uczyni świadczącego swym spadkobiercą, to zarówno w prawie rzymskim, niemieckim, jak i polskim umowy co do spadku po osobie żyjącej nie są ważne ${ }^{52}$, dlatego strony nie mogą zawrzeć skutecznie umowy, w której odbiorca świadczenia

50 C.M. LACHNER, op. cit., s. 22.

51 C.M. Lachner, op. cit., s. 32; K. Larenz, C.W. Canaris, op. cit., s. 151; A. Röthel, op. cit., s. 1247; H.J. WiELING, op. cit., s. 26.

52 W prawie rzymskim uznawano je za sprzeczne $z$ dobrymi obyczajami, w prawie współczesnym nieważność wynika wprost z przepisów; zob. \$2302 BGB i art. 1047 k.c. 
zobowiąże się ustanowić świadczącego spadkobiercą testamentowym, ani tym bardziej umowy, w której go takim spadkobiercą ustanawia. Nie oznacza to jednak, że uzgodnienie stron w tym przedmiocie jest zupełnie pozbawione znaczenia prawnego i nie może być traktowane jako porozumienie co do podstawy świadczenia. Zwykle też problem pojawia się w tych przypadkach, w których po śmierci spadkodawcy okazuje się, że na krótko przed śmiercią zmienił testament i w miejsce świadczącego ustanowił spadkobiercą inną osobę. Zaskoczony tą wiadomością świadczący dowiaduje się, że spadkodawca zachował się wbrew nieformalnemu porozumieniu. Porozumienie takie zwykle też nie przybiera formy pisemnej ani tym bardziej formy wyższej, skoro i tak nie może wywołać skutku w postaci zobowiązania odbiorcy świadczenia.

Założenie niedopuszczalności zastosowania condictio ob rem w odniesieniu do zaskarżalnych zobowiązań ma charakter fundamentalny, stanowiąc tym samym najistotniejszy argument przemawiający za wąskim rozumieniem celu świadczenia. Stąd też celem tym nie może być uzyskanie możliwego do wyegzekwowania na drodze sądowej świadczenia wzajemnego. Z tej przyczyny w przywoływanym wyżej wyroku z 17 stycznia 2002 r., jak i w późniejszym polskim orzecznictwie mowa jest o tym, że odbiorca świadczenia nie staje się zobowiązany do egzekwowalnego świadczenia wzajemnego, a samo porozumienie co do podstawy prawnej świadczenia jest jednak kategorią szczególną, odróżnianą od typowej, tj. kreującej roszczenia, umowy ${ }^{53}$.

Istnienie kategorii umów, których wykonanie zależy jedynie od dobrej woli stron i które opierają się na wzajemnym zaufaniu stron, nie jest niczym osobliwym ani nowym. Zanim ostatecznie zatriumfowała zasada swobody umów, wiele umów pozbawionych ochrony prawnej było zawieranych przy pełnej świadomości braku roszczenia o ich wykonanie, ale w zaufaniu, że druga strona wykona swe zobowiązanie. W prawie rzymskim nie funkcjonowałaby bogata kategoria umów typu do ut des, do ut facias, facio ut des lub facio ut facias, nazwanych później

53 Jak to ujął Sąd Najwyższy, porozumienie woli stron co do podstawy prawnej świadczenia nie jest czynnością prawną, która stanowiłaby źródło roszczeń spełniającego świadczenie (wyrok z 13 czerwca 2019 r., V CSK 43/18). 
kontraktami nienazwanymi, jeżeli Rzymianie nie mieliby do siebie zaufania, że mimo braku zaskarżalności zostaną one wykonane ${ }^{54}$. Gdyby takie niezaskarżalne umowy miały charakter marginalny, to juryści klasyczni by się nimi nie zajmowali, a kompilatorzy nie poświęciliby im oddzielnego tytułu w Digestach ${ }^{55}$. Doświadczenie historyczne uczy jednak, że już w antyku dostrzeżono, iż takie umowy powinny stać się zaskarżalne, dlatego stopniowo taką zaskarżalność uzyskały.

Jeżeli w takim porozumieniu odbiorca zobowiąże się do świadczenia wzajemnego, to wykonanie takiego zobowiązania będzie zależało wyłącznie od jego dobrej woli, a jedyną sankcją, która może go dotknąć, jest konieczność zwrotu otrzymanego świadczenia. Porozumienie to stanowi zatem wyraz zaufania, jakim darzą się jego strony, bowiem ta strona, która zdecyduje się świadczyć jako pierwsza, działa w zaufaniu, że druga strona wywiąże się z podjętych uzgodnień lub że nastąpi inny stan rzeczy zakładany przez strony. Roszczenie o zwrot własnego świadczenia na wypadek, gdyby odbiorca nie wykonał zobowiązania, stanowi instrument ochrony prawnej świadczącego o charakterze minimalnym, ale zarazem w tej sytuacji wyczerpującym.

Kolejną przesłanką wyznaczającą zakres zastosowania condictio ob rem jest założenie, że zakresy zastosowania poszczególnych kondykcji nie mogą się pokrywać ani krzyżować, a zatem że w danym stanie faktycznym wchodzi w rachubę tylko jedna $\mathrm{z}$ nich ${ }^{56}$. Pozostałe kondykcje nie budzą aż tak dużych kontrowersji, także w aspekcie zakresu ich stosowania. Oznacza to, że condictio ob rem nie służy zwłaszcza odzyskaniu świadczenia spełnionego w błędnym przekonaniu istnienia obowiązku świadczenia lub w wykonaniu nieważnej czynności prawnej.

54 Dość wspomnieć, że do tej kategorii należały tak istotne umowy, jak zamiana (permutatio), aestimatum, z którego wywodzi się współczesna umowa komisu, i ugoda (transactio).

55 Tytuł D. 19,5 De praescriptis verbis et in factum actionibus (O skargach $\mathrm{z}$ kontraktów opartych na słowach lub okolicznościach faktycznych).

56 A. Röthel, op. cit., s. 1246; A. Ohanowicz, Bezpodstawne wzbogacenie, [w:] A. Ohanowicz, Wybór prac, red. A. Gulczyński, Warszawa 2007, s. 1032; W. SerdA, op. cit., s. 93; E. ŁęTOWsKA, op. cit., s. 84; P. KsıĘŻAK, Kodeks cywilny..., uwaga 89 do art. 410; wyroki SN z: 13 października 2011 r., V CSK 483/10; z 5 czerwca 2019 r., V CSK $265 / 18$. 
W przeciwieństwie zaś do condictio indebiti, ma zastosowanie w tych sytuacjach, w których świadczący wiedział, że nie jest obowiązany do świadczenia, lecz kierował się celem aprobowanym przez odbiorcę. Stanowi to kolejną przyczynę wąskiego zakresu zastosowania condictio ob rem i formułowania cech różnicujących ją od pozostałych kondykcji.

W rzymskim prawie klasycznym problem ten przedstawiał się inaczej, ponieważ istniała jedynie condictio jako jednolita skarga procesowa, służąca między innymi uzyskaniu zwrotu świadczenia nienależnego. Co prawda na gruncie prawa materialnego condictio była stosowana w określonych podobnych do siebie pogrupowanych przypadkach ${ }^{57}$, nie było jednak konieczności przeprowadzenia między tymi grupami przejrzystych rozróżnień ${ }^{58}$. Dopiero najwcześniej w prawie poklasycznym, o ile nie w justyniańskim, wyróżniono tzw. figury condictiones, znane z kompilacji justyniańskiej. Wtedy zatem pojawił się problem, która $\mathrm{z}$ tych figur powinna mieć zastosowanie w danej sytuacji. Praktyka współczesna pokazuje jednak, że znacznie ważniejsze od problemu odróżniania od siebie poszczególnych kondykcji ${ }^{59}$ jest ich odróżnienie od roszczeń kontraktowych oraz odpowiedź na pytanie, czy w danym przypadku świadczenie w ogóle podlega zwrotowi, na jakiejkolwiek podstawie prawnej ${ }^{60}$.

57 Najlepszym dowodem tego jest zestawienie poszczególnych rodzajów świadczeń (datio) w D. 12,6,65pr.- 4; zob. M. Soвсzy к, Świadczenie..., s. 152 i n. z przywoływaną tam literaturą.

58 Nie jest jasne, zwłaszcza dlaczego późnoklasyczny jurysta Paulus w D. 12,6,65pr.-4 obok dwóch tradycyjnie wyróżnianych datio ob rem i datio ob causam wyróżnił datio propter condicionem (świadczenia w celu dopełnienia warunku) i propter transactionem (świadczenia na poczet umowy ugody). Sporny jest także wzajemny stosunek datio ob $\mathrm{rem} / \mathrm{causam}$ i datio ob turpem causam (świadczenia w celu niegodziwym).

59 Stosunkowo często sąd zadowala się argumentem, że zwrot świadczenia następuje na podstawie art. $410 \$ 2$ k.c. bez wnikania w poszczególne kondykcje, a nawet że następuje na podstawie „bezpodstawnego wzbogacenia”.

${ }_{60}$ Przykładem tego dylematu są rozliczenia stron zakończonych już związków partnerskich. 


\section{Przedmiot porozumienia Co do PODSTAWy PRAWNeJ ŚWIADCZENIA}

Dopełnienie charakteru porozumienia określeniem „co do podstawy prawnej świadczenia" wskazuje na przedmiot porozumienia. Jest nim bowiem jedynie ustalenie celu, ze względu na który następuje świadczenie, a nie kreacja roszczeń (zaskarżalnych zobowiązań). Z porozumienia wynika jedynie to, dlaczego zostało spełnione świadczenie i czego strony oczekują w przyszłości, nie wynikają natomiast żadne chronione prawnie roszczenia o jego wykonanie. Treść porozumienia pełni zatem funkcję obrazującą ustalenia stron w przedmiocie wyłącznie celu świadczenia, co ma znaczenie jako przyszła podstawa prawna świadczenia lub podstawa roszczenia o zwrot świadczenia, nie stanowi zaś argumentu za formułowaniem roszczeń o wykonanie uzgodnionych w porozumieniu zobowiązań. Wyznaczając cel świadczenia, porozumienie określa zarazem okoliczność, której weryfikacja negatywna - nieosiągnięcie celu świadczenia - uprawnia do żądania zwrotu świadczenia, zaś pozytywna przesądza o zaistnieniu trwałej podstawy prawnej świadczenia ${ }^{61}$. Tym samym z treści porozumienia wynika, dlaczego zostało spełnione świadczenie i zarazem jaki jest uzgodniony przez strony cel świadczenia i jednocześnie przyszła podstawa prawna świadczenia, której urzeczywistnienia strony oczekują, oraz że w przypadku gdyby cel ten nie został osiągnięty, powstanie obowiązek zwrotu świadczenia. Innymi słowy, porozumienie dookreśla okoliczności z jednej strony uprawniające odbiorcę do zachowania na stałe świadczenia, a z drugiej strony uprawniające świadczącego do żądania zwrotu świadczenia.

Porozumienie przesądza także o tym, że przesunięcie majątkowe, które następuje wskutek świadczenia, do chwili weryfikacji, czy cel świadczenia zostanie osiągnięty, ma w założeniu charakter tymczasowy lub prowizoryczny. W tym okresie przejściowym to świadczenie jest potencjalnie zwrotne w przyszłości. Dopiero po pozytywnej weryfikacji

${ }^{61}$ W doktrynie polskiej bardzo podkreśla się, że w przypadku tej kondykcji podstawa prawna świadczenia jeszcze nie istnieje, ale ma zaistnieć w przyszłości; zob. A. Ohanowicz, Niesłuszne wzbogacenie, s. 836 i n.; P. KsıĘżaK, Kodeks cywilny..., uwaga 89 do art. 410 . 
tej okoliczności przez osiągnięcie celu świadczenia to przesunięcie majątkowe uzyskuje trwały charakter i uprawnia przyjmującego świadczenie do jego zachowania. Zwrotny charakter świadczenia uzależniony od weryfikacji celu świadczenia wynika $z$ samej istoty porozumienia i nie musi być w jego treści explicite zastrzegany ${ }^{62}$. Jego wyraźne uzgodnienie może wszakże rozwiać ewentualne wątpliwości dotyczące zgodnej woli stron i ewidentnie zwiększa szansę powodzenia procesowego dochodzenia roszczenia powoda. Co więcej, wydaje się, że jeżeli strony wyraźnie uzgodniłyby zwrot świadczenia w przypadku nieosiągnięcia jego celu, to żądanie zwrotu świadczenia wynikałoby właśnie $\mathrm{z}$ umowy, która w tym zakresie kreowałaby wymuszalne zobowiązanie, bez potrzeby podnoszenia jako podstawy roszczenia condictio ob rem ${ }^{63}$.

Kolejną ważną funkcją porozumienia co do podstawy prawnej świadczenia jest stworzenie podstawy prawnej do zatrzymania świadczenia przez jego odbiorcę do chwili, w której okaże się, czy cel świadczenia zostaje osiągnięty, a zatem tak długo, dopóki zamierzony cel może być jeszcze zrealizowany ${ }^{64}$. W założeniu taka podstawa prawna zatrzymania świadczenia ma charakter przejściowy, bowiem gdy cel świadczenia zostanie osiągnięty, odbiorca uzyskuje ostateczne i trwałe prawo do jego zachowania, a jeżeli cel świadczenia nie zostaje osiągnięty, to odbiorca traci podstawę do jego zatrzymania i staje się obowiązany do jego zwrotu świadczącemu. Właściwa i trwała podstawa prawna świadczenia ma zatem dopiero powstać w przyszłości po zrealizowaniu celu świadczenia. W stanie przejściowym, w którym strony oczekują na realizację celu świadczenia, odbiorca ma prawo je zatrzymać i nie staje się obowiązany do jego zwrotu, nawet gdyby tego zażądał sam świadczący,

62 M. LiEB, op. cit., s. 1310.

63 Bez względu na ewentualne zarzuty co do poprawności jurydycznej tego rozumowania można rozsądnie założyć, że w większości takich przypadków podstawą żądania powoda byłaby właśnie umowa, a strony i sąd rozpoznający sprawę nie dostrzegaliby nawet potrzeby sięgania do condictio ob rem.

64 D. Reuter, M. Martinek, op. cit., s. 150; G. Welker, op. cit., s. 32; M. Weber, op. cit., s. 25; C.M. LACHNer, op. cit., s. 28; K. LAREnZ, W.C. CANARIs, op. cit., s. 152; M. Lieb, op. cit., s. 1310. W literaturze polskiej zob. W. SERDA, op. cit., s. 97; P. KsıĘżAK, Kodeks cywilny..., uwaga 96 do art. 410. W orzecznictwie zob. wyroki SN z 17 stycznia 2002 r., III CKN 1500/00 i z 13 czerwca 2019 r., V CSK 43/18. 
oświadczając przy tym, że rezygnuje z osiągnięcia celu świadczenia. Podstawa zatrzymania świadczenia, choć nie jest trwała, to jest jednak wystarczająco solidna, aby ochronić odbiorcę przed przedwczesnym roszczeniem restytucyjnym ${ }^{65}$. Niemniej uważam, że ówcześnie przyjmujący świadczenie powinien liczyć się z obowiązkiem jego zwrotu na wypadek braku realizacji celu świadczenia.

Podkreślenia wymaga także, że porozumienie co do podstawy prawnej świadczenia wiąże strony w tym aspekcie, iż świadczący nie może swobodnie odstąpić od niego, oświadczając odbiorcy świadczenia, że rezygnuje z potrzeby realizacji celu świadczenia i żąda zwrotu świadczenia ${ }^{66}$. Potrzeba realizacji celu świadczenia i możliwość rezygnacji z niej nie pozostaje wyłącznie w gestii świadczącego, wbrew woli odbiorcy świadczenia. Pod tym względem prawo rzymskie znało inne rozwiązanie w postaci prawa do jednostronnej rezygnacji z osiągnięcia celu świadczenia (ius poenitendi) ${ }^{67}$. I tak osoba, która poczyniła darowiznę na wypadek śmierci (donatio mortis causa), stanowiącą jeden z podstawowych przykładów świadczeń w zamierzonym celu (datio ob rem), mogła w każdym czasie żądać zwrotu darowizny, gdyż ta stawała się ostateczna dopiero z chwilą jej śmierci, a zatem dopiero z tą chwilą następowała właściwa weryfikacja realizacji celu świadczenia ${ }^{68}$. W toku historii odrzucono ius poenitendi jako instrument prawny godzący w wiążący charakter umów. Ius poenitendi zostało całkowicie wyeliminowane, dlatego nie ma ono zastosowania także na gruncie porozumień wyznaczających cel świadczenia i zarazem przejściową podstawę prawną jego zatrzymania.

Strony mogą zgodnie, choćby w sposób dorozumiany, rozwiązać porozumienie, rezygnując tym samym z potrzeby osiągnięcia jego celu. Od rezygnacji z potrzeby realizacji celu świadczenia należy odróżnić

65 D. Reuter, M. Martinek, op. cit., s. 150; G. Welker, op. cit., s. 36 i n.; C.M. LaChNer, op. cit., s. 28; M. Lieb, op. cit., s. 1310; H.J. Wieling, op. cit., s. 30; P. KsiężaK, Kodeks cywilny..., uwaga 96 do art. 410.

66 Por. M. Lieb, op. cit., s. 1309.

${ }_{67}$ Zakres, w jakim na poszczególnych etapach rozwoju prawa rzymskiego świadczący mógł skorzystać z ius poenitendi, jest w nauce bardzo sporny; zob. szerzej M. Soвсzyк, Świadczenie..., s. 255 i n.

68 Szerzej M. Sовсzy к, Świadczenie..., s. 168 i n., s. 277. 
zniweczenie możliwości osiągnięcia tego celu jednostronnym działaniem świadczącego. Świadczący nie oświadcza tu bowiem, że rezygnuje z potrzeby realizacji celu świadczenia, lecz podejmuje działania ją uniemożliwiające, co może mieć miejsce oczywiście w tych sytuacjach, w których świadczący w ogóle ma wpływ na tę realizację.

Współczesnym przykładem takiej sytuacji jest zerwanie konkubinatu (związku partnerskiego) przez tego partnera, który wcześniej poczynił spore świadczenia mające na względzie dalsze trwanie związku lub jego sformalizowanie. Zerwanie takiego związku jest równoznaczne zniweczeniu możliwości osiągnięcia celu świadczenia. Powstaje pytanie, czy $\mathrm{w}$ takiej sytuacji świadczącemu przysługuje roszczenie restytucyjne, skoro ponosi odpowiedzialność za nieosiągnięcie celu świadczenia. W tym aspekcie prawo rzymskie uprawniało świadczącego do zwrotu świadczenia, nawet gdy to on zapobiegł osiągnięciu celu świadczenia. Ojciec, który ustanowił i przekazał świadczenie tytułem posagu osobie, która miała zostać w przyszłości jego zięciem, mógł żądać zwrotu świadczenia nawet wtedy, gdy zapobiegł zawarciu planowanego małżeństwa ${ }^{69}$. Podobnie współcześnie co do zasady przyczyny nieosiągnięcia celu świadczenia nie mają wpływu na istnienie prawa do żądania jego zwrotu ${ }^{70}$. Natomiast $\$ 815$ BGB wyraźnie pozbawia świadczącego roszczenia o zwrot świadczenia, jeżeli wbrew zasadom uczciwości i zaufania przeszkodził temu, by skutek nastąpił. Nie wystarczy zatem, że świadczący zapobiegł realizacji celu świadczenia, lecz jego zachowanie powinno mieć charakter naganny w takim stopniu, że można $\mathrm{mu}$ postawić zarzut działania w złej wierze. Także w prawie polskim w niektórych sytuacjach będzie można podnieść wobec roszczenia restytucyjnego zarzut nadużycia prawa lub analogicznie zastosować art. 93 k.c. ${ }^{71}$ Uważam jednak, że nie przeczy to zasadzie, iż świadczenie

69 Ibidem, s. $275 \mathrm{i} \mathrm{n}$.

70 Por. W. Dubis, op. cit., uwaga 13 do art. 410. Zbyt kategoryczna wydaje się teza P. Księżaka, że jeżeli solvens sam doprowadził do niezrealizowania się celu świadczenia, jego kondykcja będzie wyłączona (P. Ksı̨̨żAK, Bezpodstawne wzbogacenie..., s. 193; IDEM, Kodeks cywilny..., uwaga 94 do art. 410).

71 Por. P. Ksı̨̨żAK, Kodeks cywilny..., uwaga 94 do art. 410 k.c.; W. Dubis, op. cit., uwaga 13 do art. 410 . 
podlega zwrotowi bez względu na przyczyny niezrealizowania się celu świadczenia i nawet w przypadku, gdy to świadczący przeszkodził realizacji celu świadczenia, nie można bezrefleksyjnie pozbawić go prawa żądania zwrotu świadczenia.

\section{CZY CELEM ŚWIADCZENIA MOŻE BYĆ JEDYNIE UZYSKANIE ŚWIADCZENIA EKWIWALENTNEGO?}

W przytoczonym wyżej uzasadnieniu wyroku Sądu Najwyższego z 17 stycznia 2002 r., III CKN 1500/00, jako podstawowe wymaganie uznania, że cel świadczenia nie został osiągnięty w rozumieniu art. 410 $\$ 2$ k.c., wskazano okoliczność, że „celem świadczenia było otrzymanie zamierzonego ekwiwalentnego świadczenia od odbiorcy". Taki właśnie cel świadczenia podkreślany jest także w późniejszym orzecznictwie ${ }^{72}$. Dlaczego celem świadczenia ma być otrzymanie ekwiwalentnego świadczenia od odbiorcy i to jeszcze ekwiwalentnego? Przecież wymaganie to nie wynika ani z treści przepisu, ani z wykładni systemowej. Odpowiedź na to pytanie jest znacznie trudniejsza i bardziej złożona niż powyższe dylematy dotyczące porozumienia co do podstawy świadczenia. Co więcej, uważam, że zawężenie celu świadczenia do otrzymania świadczenia wzajemnego, w dodatku ekwiwalentnego, jest nieuzasadnione. Tym razem argumenty wywodzone $\mathrm{z}$ historii prawa zupełnie temu przeczą, a nadto także prawo pozytywne dostarcza argumentów za znacznie szerszą wykładnią celu świadczenia. Paradoksalnie, to zawężenie także zostało przejęte z doktryny niemieckiej, tyle tylko że doktryna niemiecka oparła się tutaj między innymi na błędnych wnioskach z badań nad prawem rzymskim i obecnie znaczna jej część porzuciła już tę wąską koncepcję.

Sama treść $\$ 812$ I zd. 2 al. 2 BGB nie zawiera wymagania, aby zamierzonym skutkiem świadczenia było uzyskanie świadczenia wzajemnego.

72 Zob. wyroki SN: z 21 czerwca 2011 r., I CSK 533/10; z 13 października 2011 r., V CSK 483/10; z 15 kwietnia 2015 r., IV CSK 456/14; z 21 kwietnia 2016 r., III CNP 18/15; z 25 maja 2018 r., I CSK 482/17; z 13 czerwca 2019 r., V CSK 43/18. 
Rozważana w toku prac kodyfikacyjnych koncepcja „założenia” nie zawężała celu świadczenia do uzyskania świadczenia wzajemnego. Lektura protokołów komisji kodyfikacyjnej nie wskazuje na to, aby brano je pod uwagę. Nawet najstarsze orzecznictwo do tego przepisu także nie zawiera takiego wymagania, przeciwnie, wskazuje na znacznie szersze rozumienie terminu „zamierzony skutek świadczenia”’3.

$\mathrm{W}$ połowie XX w. ukazały się jednak prace, które zmieniły wykładnię przepisu, zawężając skutek świadczenia do uzyskania niewymuszalnego świadczenia wzajemnego. Cywiliści wywodzili argumenty między innymi z procesu ewolucji kondykcji i ze znanych im badań nad prawem rzymskim, a tu akurat Fritz Schwarz opublikował w 1952 r. rozprawę, w której usiłował wykazać, że rzymska condictio ob rem była stosowana w prawie klasycznym wyłącznie w przypadku, w którym celem świadczenia było uzyskanie świadczenia wzajemnego ${ }^{74}$. Choć pogląd ten w romanistyce wydaje się już zarzucony ${ }^{75}$, to posłużył on jako jeden $\mathrm{z}$ najistotniejszych argumentów za twierdzeniem, że współczesne roszczenie $\mathrm{z}$ \$ 812 I zd. 2 al. 2 BGB także zawęża się do sytuacji, w której skutkiem świadczenia było uzyskanie świadczenia wzajemnego (Gegenleistung $)^{76}$. Znaczna część doktryny niemieckiej przejęła tę koncepcję̧, a za nią, zwłaszcza po cytowanym wyroku Sądu Najwyższego z 2002 r., także polskie orzecznictwo ${ }^{78} \mathrm{i}$ wielu komentatorów art. 410 k.c. $^{79}$

To wąskie rozumienie celu świadczenia w rzeczywistości nie znajduje oparcia w prawie rzymskim, wręcz przeciwnie, cel świadczenia Rzymianie rozumieli znacznie szerzej. Aby nie przytaczać tu wielu przypadków

73 Zob. sprawy przywoływane w: C.M. LACHNER, op. cit., s. 67.

74 F. Schwarz, Die Grundlage der, condictio' im klassischen römischen Recht, Münster-Köln 1952, s. 117 i n.

75 Szeroko opisuję poglądy romanistów w tej kwestii w: Świadczenie..., s. 121 i n.

76 Tak przede wszystkim A. SöLlner, Der Bereicherungsanspruch wegen Nichteintritts des mit einer Leistung bezweckten Erfolges (\$ 812 Abs. 1 S. 2, 2 Halbsatz BGB), «Archiv für die civilistische Praxis» 163/1963, s. 20-45.

77 D. Reuter, M. Martinek, op. cit., s. 170; K. Larenz, C.W. Canaris, op. cit., s. 151; M. Weber, op. cit., s. 25 i n.; A. Röthel, op. cit., s. 1247.

78 Zob. wyrok SN z 25 maja 2018 r., I CSK 482/17.

79 Zob. K. Pietrzy Kowski, w: Kodeks cywilny, red. K. Pietrzy Kowski, «Legalis» 2020, nb 13 do art. 410. 
zastosowania condictio ob rem $\mathrm{w}$ prawie rzymskim ${ }^{80}$, ograniczę się do dwóch przykładów, w których nie można uznać, że celem świadczenia było uzyskanie świadczenia wzajemnego: świadczenie tytułem posagu na poczet małżeństwa, które miało zostać w przyszłości zawarte, a które nie doszło do skutku ${ }^{81}$, i darowizna na wypadek śmierci (donatio mortis causa), kiedy to darczyńca, działając w sytuacji zagrożenia życia, dokonywał darowizny na rzecz innej osoby, tj. przenosił na nią własność rzeczy, ale z takim skutkiem, że miał prawo żądać zwrotu tej darowizny, gdy niebezpieczeństwo utraty życia ustało lub gdy obdarowany zmarł przed nim, a w prawie poklasycznym także wtedy, gdy po prostu zmienił zdanie (ius poenitendi) ${ }^{82}$. Trudno traktować zawarcie małżeństwa jako świadczenie wzajemne za otrzymany wcześniej posag, a odbiorcę posagu jako dłużnika obowiązanego do zawarcia małżeństwa. Tym bardziej nie można mówić o świadczeniu wzajemnym w przypadku darowizny na wypadek śmierci, bowiem tu celem świadczenia nie tylko nie było uzyskanie świadczenia wzajemnego, ale cel ten w ogóle nie odnosił się do jakiegokolwiek zachowania odbiorcy świadczenia. W obu tych przypadkach świadczenie następowało ze względu na pewne okoliczności - planowane zawarcie małżeństwa lub wolę podarowania wybranej osobie jakiejś rzeczy w obawie zagrożenia życia - ale nie ze względu na uzgodnione i oczekiwane świadczenie wzajemne.

Także nieliczne wypowiedzi jurystów rzymskich w sposób ogólny charakteryzujące condictio ob rem świadczą o szerokim rozumieniu terminu res, wypartego z czasem przez causa. Świadczą o tym takie

80 Do tego odnoszę się szczegółowo w: Świadczenie..., s. 121 i n., i Problem wykładni „celu świadczenia” w rozumieniu art. $410 \$ 2$ polskiego kodeksu cywilnego: argumenty historyka prawa rzymskiego, "Miscellanea Historico-Iuridica» 2/2018, s. 215 i n.

${ }^{81}$ Zob. M. Sовсzyк, Świadczenie..., s. 163 i n.; IDEm, Problem wykładni..., s. 215 i n.

82 Wariantów realizacji donatio mortis causa w prawie rzymskim było kilka. W tym miejscu przytaczam jedynie najbardziej podstawowy przykład. Do pozostałych odnoszę się w pracach przywoływanych w przypisie poprzedzającym oraz w pracy Rzymska koncepcja darowizny na wypadek śmierci w komentarzu Paulusa do lex Iulia et Papia (D.39.6.35.2-3), «Studia Iuridica Toruniensia» 10/2012, s. 50-71; IDEM, Donation in contemplation of death as an example of datio ob rem in Roman law, "Studia Iuridica Toruniensia» 23/2018, s. 291-308. 
sformułowania, że świadczenie zostało spełnione, aby coś nastąpiło (ut aliquid sequatur) ${ }^{83}$, aby coś się stało (ut aliquid fieret) ${ }^{84}$, aby coś się wydarzyło (ut aliquid optingat) ${ }^{85}$. Koncepcja celu świadczenia była zatem szeroka i mogła odnosić się do bliżej określonego stanu rzeczy oczekiwanego w przyszłości, nie tylko do świadczenia wzajemnego oczekiwanego od odbiorcy świadczenia lub też zachowania odbiorcy niestanowiącego świadczenia.

W doktrynie niemieckiej także zauważono, że ograniczenie skutku świadczenia do niewymuszalnego świadczenia wzajemnego nie jest uzasadnione ani argumentami historycznymi, ani systemową wykładnią przepisów BGB, ani argumentami odwołującymi się do celu regulacji prawnej. Przede wszystkim Detlef Liebs wykazał, że w swoim rozwoju historycznym condictio ob rem była stosowana znacznie szerzej niż tylko w przypadku niezaskarżalnych umów, w których strony zobowiązywały się do świadczeń wzajemnych ${ }^{86}$. Osobiście nie mam co do tego wątpliwości, stąd próby ograniczenia celu świadczenia do niewymuszalnego świadczenia wzajemnego motywowane argumentem, że tak było w prawie rzymskim, uważam za nieporozumienie ${ }^{87}$. Wyniki badań Liebsa uwzględnili badacze prawa pozytywnego, którzy ponadto wykazali, że również we współczesności skutek świadczenia należy rozumieć szeroko ${ }^{88}$.

Także w polskim orzecznictwie niekiedy zauważa się, że celem świadczenia „może być dowolny stan faktyczny uzgodniony albo przynajmniej znany obu stronom, zwłaszcza może być to cel prawny lub gospodarczy"89. To elastyczne podejście podzielane jest przez część doktryny, gdyż podkreśla się, że cel może być, co do zasady, dowolnym,

83 D. 12,6,52 (Pomp. 27 ad Q. Muc.).

84 D. 12,1,19pr. (Iul. 10 dig.).

85 D. 39,6,35,3 (Paul. 6 ad l. Iul et Pap.).

86 D. Liebs, op. cit., s. 697 i n.

87 Zob. szerzej M. SobCzy , Świadczenie..., s. 121 i n.; IDEM, Problem wykładni..., s. $221 \mathrm{i} \mathrm{n.}$

88 O. MüHL, W. HAdDing, op. cit., s. 1142 i n.; H.J. Wieling, op. cit., s. 25 i n.

89 Wyroki SN: z 13 października 2011 r., V CSK 483/10; z 21 kwietnia 2016 r., III CNP 18/15; z 16 czerwca 2016 r., V CSK 581/15; z 5 czerwca 2019 r., V CSK 265/18; wyrok SA w Szczecinie z 14 maja 2015 r., I ACa 60/15. Na szerszą formułę celu świadczenia wskazują 
przyszłym dozwolonym stanem faktycznym ${ }^{90}$. Wydaje się jednak, że pogląd ten, choć nie jest nowy, dopiero zyskuje uznanie, a nadto często jest wskazywany na drugim miejscu po poglądzie tradycyjnym ${ }^{91}$. W literaturze określa się go jako szersze, liberalniejsze ujęcie celu świadczenia, obok poglądu tradycyjnego mającego rzymskie korzenie, jednak bez dostrzeżenia, że ów pogląd tradycyjny tak naprawdę oparty jest na zawężającej interpretacji źródeł rzymskich ${ }^{92}$. Paradoksalnie zatem to nie węższe, lecz szersze ujęcie celu świadczenia odpowiada prawidłowo odczytywanym źródłom rzymskim.

Dalsze trwanie związku partnerskiego lub jego sformalizowanie nie jest świadczeniem wzajemnym ze strony partnera. Zastrzegam w tym miejscu, że nie mam tu na myśli ekstremalnych sytuacji, w których strona związku płaci za to, aby partner przy niej pozostał i zobowiązywał się, że jej nigdy nie opuści. Takie porozumienie w ogóle nie wywierałoby skutków prawnych, wobec czego nie zobowiązywałoby do żadnych świadczeń. Ustanowienie świadczącego spadkobiercą także trudno uważać za świadczenie wzajemne. Należy jednak podkreślić, że oba te przykłady celu świadczenia odnoszą się do zachowania odbiorcy świadczenia oczekiwanego przez świadczącego, oba wiąże się z korzyścią majątkową lub osobistą świadczącego, a nadto osiągnięcie obu celów świadczenia zależy od woli odbiorcy świadczenia. Teoretycznie można zatem rozważać, czy przykładów tych nie można podciągnąć pod pojęcie

także: wyrok SN z 17 marca 2011 r., IV CSK 344/10; wyrok SA w Szczecinie z 8 maja 2013 r., I ACa 182/13; wyrok SA w Katowicach z 29 marca 2017 r., I ACa 1026/16.

90 A. Ohanowicz, Niesłuszne wzbogacenie, s. 837 i n.; IdEm, Bezpodstawne wzbogacenie..., s. 1032; W. SERDA, op. cit., s. 92 i n.; E. ŁęTOWsKA, op. cit., s. 98 i n.; P. Mostowik, Bezpodstawne wzbogacenie, «Studia Prawa Prywatnego» 2.5/2007, s. 84; P. KsıĘżAK, Bezpodstawne wzbogacenie..., s. 191; IDEM, Kodeks..., uwaga 89 do art. 410; A. Rzetecka-Gil, op. cit., uwaga 23 do art. 410; G. KArAszewski, op. cit., uwaga 3 do art. 410; R. Trzaskowski, op. cit., uwagi 18 i 23 do art. 410.

91 Zob. wyroki SN z 13 października 2011 r., V CSK 483/10, i z 16 czerwca 2016 r., V CSK 581/15; z 5 czerwca 2019 r., V CSK 265/18; R. TrZaskowski, op. cit., uwaga 23 do art. 410.

92 E. Łętowska, op. cit., s. 98. Paradoksalnie W. Serda uważa, że zgodne z tradycją rzymską jest jedynie wąskie ujęcie (W. SERDA, op. cit., s. 94). 
świadczenia wzajemnego, ale $\mathrm{w}$ takim przypadku pojęciu temu nadano by swoistą, bardzo szeroką treść.

\section{Cel a motyw świadczenia}

Nie ulega wątpliwości, że przez pojęcie zamierzonego skutku lub celu świadczenia nie należy rozumieć zwykłego motywu, którym kierował się świadczący, spełniając świadczenie ${ }^{93}$. Podany wyżej przykład drogiego prezentu wręczanego $\mathrm{w}$ intencji pozyskania przyjaźni obdarowanego albo jego przychylności w jakiejś sprawie stanowi przykład takiego motywu. Odróżnienie celu świadczenia od motywu nie jest jednak łatwe, bowiem trudno jest wskazać użyteczne i proste w zastosowaniu kryteria, które powinny być brane pod uwagę. Nie oznacza to jednak, że odróżnienie to może opierać się wyłącznie na intuicji.

W nauce panuje zgoda co do tego, że cel świadczenia jest czymś więcej niż motywem, jednakże zarazem czymś mniej niż technicznie rozumiany warunek jako accidentale negotii czynności prawnej ${ }^{94}$. Innymi słowy, cel świadczenia sytuuje się między motywem a warunkiem. Nie jest celem świadczenia zwykła nadzieja na coś, wyobrażenie lub jednostronne oczekiwanie nawet wzbudzone postawą drugiej strony ${ }^{95}$. Nie można jednak wskazać „wagi” lub „istotności” celu świadczenia $\mathrm{z}$ matematyczną precyzją i in concreto stosować w stosunku do niego skali porównawczej z motywem lub warunkiem. Siłą rzeczy aspekt ten jest dość ocenny i subiektywny. Można jednak sformułować pewne

93 Wyrok BGH z 10 listopada 2003 r., II ZR 250/11; wyroki SN z 17 stycznia 2002 r., III CKN 1500/00; z 13 czerwca 2019 r., V CSK 43/18; wyrok SA w Warszawie z 2 października 2013 r., I ACa 354/13; M. LieB, op. cit., s. 1310; H. GrAmM, op. cit., s. 1191; A. Röthel, op. cit., s. 1247; H.J. Wieling, op. cit., s. 31; P. Ksı̨̨żAK, Kodeks cywilny..., uwaga 95 do art. 410; W. DuBis, op. cit., nb 12 do art. 410; K. MularsKi, op. cit., nb 15 do art. 410 .

94 M. Lieb, op. cit., s. 1310; O. Mühl, W. Hadding, op. cit., s. 1142; H. Gramm, op. cit., s. 1191.

95 O. Mühl, W. Hadding, op. cit., s. 1142; C.M. Lachner, op. cit., s. 97; K. MuLARSKI, op. cit., nb 15 do art. 410. 
wskazówki pomocne w ocenie, czy dana okoliczność stanowi motyw, czy cel świadczenia.

Przede wszystkim bardzo istotne znaczenie w kontekście odróżnienia celu świadczenia od motywu solvensa ma fakt, że potrzeba tego odróżnienia nie powstanie na gruncie umów kreujących roszczenia, tu bowiem analizowana kondykcja w ogóle nie ma zastosowania. Tym samym, jeżeli zawarto umowę sprzedaży rzeczy, to nie ma znaczenia motyw, którym kierował się kupujący, gdyż nawet gdy jego oczekiwania okazały się płonne, nie uprawnia go to do żądania zwrotu zapłaconej ceny. Jeżeli zatem kupujący planował szybko sprzedać tę rzecz z zyskiem kolejnej osobie, a okazało się, że nie znalazł nabywcy, to sama ta okoliczność nie uprawnia go do żądania zwrotu zapłaconej ceny. Zamiar sprzedaży z zyskiem stanowi tu wyłącznie motyw kupującego, a nie cel jego świadczenia. Podstawowe założenie, że condictio ob rem nie może być stosowana na gruncie umów, z których wynikają zaskarżalne zobowiązania, czyni zbyteczną ocenę, co na gruncie takiej umowy stanowi cel świadczenia, a co jest jedynie motywem strony, znanym lub nieznanym kontrahentowi. Potrzeba takiej oceny pozostaje jedynie w sytuacjach pozostających w zakresie zastosowania tej kondykcji.

Wskazówki o najistotniejszym znaczeniu przy odróżnieniu celu świadczenia od motywu dostarcza prawo rzymskie. Cel świadczenia jest zawsze prospektywny, odnosi się do czegoś, co dopiero zgodnie z oczekiwaniami stron ma nastąpić w przyszłości. Rzymska datio ob causam nie uprawniała do condictio, jeżeli causa miała charakter praeterita, tj. odnosiła się do przeszłości. Znakomitym przykładem jest świadczenie spełnione z poczucia i dla wyrażenia wdzięczności w błędnym przekonaniu, że odbiorca świadczenia wyświadczył kiedyś świadczącemu jakąś przysługę, tutaj bowiem nie można było skorzystać z condictio po tym, jak błąd ten wyszedł na jaw ${ }^{96}$. Żadna okoliczność przeszła i teraźniejsza nie może stanowić celu świadczenia, lecz taki charakter mogą mieć wyłącznie okoliczności przyszłe.

Ta okoliczność przyszła musi mieć tak doniosły charakter, aby można ją uznać za przyczynę sprawczą świadczenia, tj. taką, bez której do

96 D. 12,6,52 і D.12,6,65,2; M. Soвсzy к, Świadczenie..., s. 133 i n. oraz 155 i n. 
świadczenia by w ogóle nie doszło ${ }^{97}$. Zarazem powinna mieć ona taki charakter, aby jej nastąpienie stanowiło podstawę trwałego zachowania świadczenia ${ }^{98}$. Nie oznacza to, że musi ona stanowić jedyną przyczynę świadczenia, ale spośród kilku zbiegających się przyczyn powinna być na tyle istotna, że bez niej świadczący nie zdecydowałby się na świadczenie, nawet jeżeli za świadczeniem przemawiałyby inne przyczyny. Partner, który decyduje się na współfinansowanie budowy domu na gruncie drugiego partnera, czyni to nie tylko $\mathrm{z}$ uwagi na perspektywę dalszego trwania związku, lecz także na potrzebę zaspokajania własnych bieżących potrzeb mieszkaniowych i życiowych. Obie te przyczyny są niewątpliwie istotne, jednakże to akurat zamiar utrzymywania związku jest tą, dla której świadczący nie poszukuje alternatywy zaspokojenia potrzeb mieszkaniowych.

Motyw wszakże również może in concreto stanowić ważny argument za spełnieniem świadczenia, co ilustruje wzmiankowany przykład drogiego prezentu, jednakże zwykle nie będzie stanowił ani przyczyny najważniejszej, ani jedynej, a zwłaszcza takiej, bez której do świadczenia by w ogóle nie doszło.

Cel świadczenia tym różni się od motywu, że zawsze musi być znany obu stronom najpóźniej w chwili świadczenia, a nigdy nie może jednostronnie przyświecać świadczącemu, pozostając nieznanym odbiorcy świadczenia ${ }^{99}$. Cel ten powinien być zatem znany odbiorcy świadczenia lub przez niego rozpoznawalny i aprobowany, co najmniej w sposób dorozumiany, tj. przez przyjęcie świadczenia w świadomości celu, którym kierował się świadczący ${ }^{100}$. Natomiast motyw może być zarówno znany, jak i nieznany odbiorcy świadczenia, choć oczywiście prostsze

97 Por. C.M. LAChner, op. cit., s. 97; H. Gramm, op. cit., s. 1191.

98 C.M. LACHNER, op. cit., s. 97.

99 D. Reuter, M. MartineK, op. cit., s. 149; C.M. LaChner, op. cit., s. 26, z przywoływanym w tych pracach orzecznictwem.

100 Orzecznictwo Federalnego Sądu Najwyższego jest w tym względzie bogate; zob. zwłaszcza wyroki z 29 listopada 1965 r., VII ZR 214/63; z 2 października 1991 r., XII ZR 145/90; z 25 listopada 2009 r., XII ZR 92/06; z 22 marca 2013 r., V ZR 28/12. Tożsamy pogląd jest wyrażany w literaturze; zob. M. Lieb, op. cit., s. 1310; O. MüHL, W. HAdding, op. cit., s. 1142. W literaturze polskiej warty odnotowania jest częściowo odmienny pogląd A. Ohanowicza, który uważał, że tylko wśród szczególnych okoliczności można 
w ocenie są sytuacje, w którym pozostał przed nim ukryty, gdyż wtedy w żadnym razie nie może uzyskać rangi celu świadczenia.

W tórne znaczenie ma tu problem, czy cel świadczenia powinien lub przynajmniej może być przedmiotem negocjacji stron, czy też jest jednostronnie wyznaczany przez świadczącego i jedynie aprobowany albo nie przez odbiorcę świadczenia. Doświadczenie historyczne wskazuje na obie możliwości, uważam zatem, że nie można twierdzić, że rola odbiorcy świadczenia sprowadza się zawsze lub przynajmniej co do zasady do akceptacji znanego mu celu, którym kieruje się świadczący, i który przez tę akceptację przestaje być jednostronnym celem świadczącego, a staje się celem świadczenia ${ }^{101}$. Nie zmienia to oczywiście faktu, że niekiedy jednej stronie bardziej zależy na realizacji celu świadczenia i zwykle to ona występuje z inicjatywą zawarcia porozumienia.

Odniesienie powyższych kryteriów do dwóch podstawowych przykładów zastosowania condictio ob rem we współczesności prowadzi do interesujących wniosków. Część doktryny uważa, że intencja osoby spełniającej świadczenie na rzecz partnera w związku partnerskim jest jedynie motywem świadczenia, nawet znanym odbiorcy, ale nie celem świadczenia ${ }^{102}$. Nie bardzo wiadomo, czym uzasadniony jest ten pogląd poza intuicją osoby, która go wyraziła. Tymczasem podane wyżej kryteria mogą okazać się pomocne w ocenie, czy jest to jedynie motyw, czy aż cel świadczenia.

Dalsze trwanie związku jest niewątpliwie okolicznością przyszłą i stanowi główną przyczynę sprawczą świadczenia, choć zwykle też nie jedyną, zwłaszcza jeżeli świadczenie ma na względzie także własne potrzeby świadczącego, na przykład wspólna budowa domu rodzinnego na gruncie stanowiącym własność jednego z partnerów. Istotność tej przyczyny sprawczej wynika głównie z więzi uczuciowych łączących partnerów, wspólnych planów życiowych, perspektywy wspólnie spędzonego życia aż do starości i śmierci. Tej przyczynie sprawczej mogą towarzyszyć także inne przyczyny, o charakterze bardziej majątkowym,

przyjąć milczącą zgodę accipiensa na cel świadczenia (A. OHanowicz, Niesłuszne wzbogacenie, s. 838).

101 Szerzej zob. M. Soвczyк, Świadczenie..., s. 194 i n.

102 M. Lieb, op. cit., s. 1315; K. Mularski, op. cit., nb 19 do art. 410. 
na przykład zamiar nieodpłatnego korzystania z nieruchomości partnera. Doniosłość tej przyczyny, która czyni z niej przyczynę sprawczą świadczenia, przemawia za uznaniem jej za cel, a nie motyw świadczenia.

Jeżeli natomiast świadczenie partnera polega na podejmowaniu zwykłej, codziennej aktywności życiowej, na przykład pieczy nad dziećmi lub wspólnym gospodarstwem domowym, to tutaj intencją świadczącego jest przede wszystkim bieżące zaspokajanie potrzeb życiowych związku. Jest to zatem okoliczność teraźniejsza, a nie przyszła, co sprzeciwia się jej uznaniu za cel świadczenia. Ponadto, nawet przy hipotetycznym uznaniu, że takie bieżące zaspokajanie potrzeb związku stanowi cel świadczenia, należałoby wyciągnąć wniosek, że jest to cel osiągany także na bieżąco, wobec czego żądanie zwrotu świadczenia nie ma tu uzasadnienia. Poza tym, zwykle czynności takie są podejmowane we współdziałaniu z drugim partnerem, który ze swej strony również podejmuje jakieś czynności służące codziennemu dobru związku. Z tych względów trudno przyjąć na przykład, aby po zerwaniu związku jeden z partnerów żądał zapłaty za opiekę nad dziećmi, a drugi zwrotu połowy kosztów utrzymania związku.

W przypadku istotnych świadczeń majątkowych zamiar pozostawania w związku jest wspólnym zamiarem stron lub co najmniej zamiarem świadczącego znanym odbiorcy świadczenia i przez niego aprobowanym. Takie dalsze trwanie związku nie musi być wprost artykułowanym wspólnym celem stron ani tym bardziej wyraźnie uzgadnianym, bowiem wystarcza, że cel ten w danych okolicznościach został wyznaczony w sposób dorozumiany i jest tym samym rozpoznawalny zarówno obiektywnie, jak i subiektywnie dla partnera, który otrzymał świadczenie. Już sama rozpoznawalność przyczyny, ze względu na którą partner zdecydował się spełnić świadczenie, przemawia za uznaniem jej za cel świadczenia. Okoliczność zatem, że motywacja, którą kieruje się świadczący, jest znana odbiorcy i że odbiorca decyduje się na przyjęcie świadczenia, stanowi argument za tym, iż stanowi ona cel świadczenia, a nie jedynie motyw świadczącego. Nie jest to wszakże argument sam w sobie przesądzający, gdyż dopiero w powiązaniu z innymi kryteriami oceny pozwala wyciągnąć wniosek, czy mamy tu do czynienia z celem świadczenia, czy jedynie z motywem. 
Przypadek świadczenia na rzecz innej osoby w oczekiwaniu nabycia spadku po niej jest bardziej skomplikowany. Stanowi to niewątpliwie okoliczność przyszłą, ale trudniej jest ocenić, czy w danym stanie faktycznym rzeczywiście stronom przyświecał taki właśnie cel świadczenia, zwłaszcza jeżeli świadczący realizował także inne cele. Przykładem może być tu sfinansowanie budowy domu na gruncie krewnego zarówno ze względu na obietnicę ustanowienia świadczącego spadkobiercą, jak i z uwagi na potrzebę zaspokajania potrzeb mieszkaniowych świadczącego w przyszłości. Tutaj świadczący finansuje budowę cudzego domu, w którym sam zamierza nieodpłatnie mieszkać w bliżej nieoznaczonej przyszłości i którego właścicielem ma zamiar się stać w drodze dziedziczenia po śmierci krewnego. Świadczący zamierza zatem realizować dwa cele i oba mają charakter bardzo istotny, oba są więcej niż motywem świadczenia. Sytuacja wydaje się stosunkowo prosta, ponieważ brak możliwości realizacji któregokolwiek z tych celów uprawnia do żądania zwrotu świadczenia (np. konieczność zmiany miejsca zamieszkania i przeprowadzki w inne miejsce). Federalny Sąd Najwyższy musiał jednak rozstrzygnąć jej znacznie trudniejszy wariant, mianowicie żądanie zwrotu świadczenia, z którym wystąpili spadkobiercy świadczącego, ten bowiem zmarł przed swoją matką, na której rzecz uprzednio spełnił świadczenie ${ }^{103}$. Sąd niższej instancji posłużył się argumentem, że cel świadczenia został osiągnięty, skoro świadczący do śmierci mieszkał w domu, który sfinansował, jego przedwczesną śmierć uznał zaś za zdarzenie mieszczące się w zakresie jego ryzyka. Sąd Najwyższy uznał jednak inaczej, bowiem nie został spełniony drugi cel świadczenia, gdyż zmarły nie może stać się niczyim spadkobiercą.

W tej grupie mieszczą się także sytuacje, w których osoba świadcząca nieodpłatnie usługi kieruje się nieujawnioną intencją, że w zamian za to odbiorca tych usług ustanowi ją swym spadkobiercą. Nie można generalnie założyć, że taka intencja jest rozpoznawalna dla odbiorcy świadczenia i że odbiorca świadczenia powinien mieć świadomość oczekiwań świadczącego i uznawać, że są one przyczyną sprawczą świadczenia.

103 Wyrok BGH z 22 marca 2013 r., V ZR 28/12. 
Tutaj odróżnienie motywu od celu świadczenia wymaga wnikliwej oceny konkretnej sprawy.

\section{WNIOsKI}

Przesłanki konstrukcyjne condictio ob rem zostały ukształtowane w toku wielowiekowej ewolucji tej kondykcji, począwszy od prawa rzymskiego. W tym bardzo długim czasie zakres jej zastosowania uległ znacznemu ograniczeniu, bowiem nie można jej stosować w odniesieniu do umów, z których wynikają roszczenia o wykonanie uzgodnionych świadczeń, ani też w obszarze zastosowania pozostałych kondykcji. Syntetyczna treść art. $410 \$ 2$ k.c., odczytywana w oderwaniu od koncepcji orzeczniczo-doktrynalnej, może prowadzić do nieporozumień.

Porozumienie co do podstawy prawnej świadczenia nie jest umową, z której wynikają zaskarżalne zobowiązania, w szczególności nie może być nim żadna z umów nazwanych. Tym bardziej, aby uniknąć nieporozumień, zasadne wydaje się utrzymanie odmienności terminologicznej porozumienia co do podstawy prawnej świadczenia i umowy.

Przedmiotem porozumienia jest wyznaczenie celu świadczenia, tj. okoliczności przyszłej, ze względu na którą następuje świadczenie, i zarazem podstawy prawnej świadczenia, której urzeczywistnienia strony oczekują w przyszłości. Właściwą podstawę prawną świadczenie uzyska dopiero po osiągnięciu celu świadczenia. Jeżeli cel świadczenia nie zostanie osiągnięty, podlega ono zwrotowi, gdyż nie uzyskało oczekiwanej podstawy prawnej.

Ważną funkcją porozumienia jest stworzenie podstawy prawnej do zatrzymania świadczenia przez jego odbiorcę do chwili, w której okaże się, czy cel świadczenia zostaje osiągnięty, a zatem tak długo, dopóki zamierzony cel może być jeszcze zrealizowany. W tym przejściowym okresie świadczący nie może skutecznie żądać zwrotu świadczenia ani też nie może rozwiązać porozumienia wbrew woli otrzymującego świadczenie.

Cel świadczenia może być dowolnym, przyszłym dozwolonym stanem faktycznym. Ograniczenie celu świadczenia do uzyskania świadczenia 
ekwiwalentnego od odbiorcy świadczenia nie jest uzasadnione ani argumentami wywodzonymi $z$ historii prawa, ani ze współczesnej dogmatyki prawa, ani potrzebami społeczno-gospodarczymi. Przeciwnie, prawidłowo odczytane źródła prawa rzymskiego sprzeciwiają się takiemu ujęciu, zaś współczesna praktyka sądowa wykazuje, że cel świadczenia należy rozumieć szerzej.

Cel świadczenia powinien być odróżniany od motywu świadczącego, przez co sytuuje się między irrelewantnym prawnie motywem a uzgodnionym przez strony warunkiem zwrotu lub zachowania spełnionego już świadczenia. W przeciwieństwie do motywu, cel świadczenia jest zawsze prospektywny i odnosi się do określonej okoliczności przyszłej. Zamiar osiągnięcia celu świadczenia stanowi przy tym przyczynę sprawczą świadczenia, tj. taką, bez której świadczenie nie zostałoby w ogóle spełnione. Nie musi to być jednak wyłączna przyczyna świadczenia, w praktyce strony mogą dążyć do realizacji nawet kilku celów.

W przeciwieństwie do motywu, cel świadczenia jest wspólny obu stronom lub co najmniej powinien być znany lub rozpoznawalny i aprobowany przez odbiorcę świadczenia, choć często jego osiągnięciem bardziej zainteresowany jest świadczący. Niekiedy wystarcza jednak, że do uzgodnienia celu świadczenia dojdzie w sposób dorozumiany, a zwłaszcza odbiorca da wyraz jego aprobaty przez sam fakt przyjęcia świadczenia. Motyw natomiast może pozostać nieznany odbiorcy świadczenia, jednakże nawet gdy jest on znany, sam ten fakt przez się nie jest wystarczającym argumentem do nadania mu rangi celu świadczenia.

PorozUmienie Co Do PODSTAWY PRAWNEJ ŚWIADCZENIA JAKO PRZESŁANKA KONSTRUKCYJNA 'CONDICTIO OB REM'

\section{Streszczenie}

Współczesna koncepcja świadczenia w zamierzonym celu, który nie został osiągnięty, uregulowana w art. $410 \$ 2$ k.c., ma swe korzenie w rzymskiej condictio ob rem. W niniejszym artykule odnoszę się do jednej z najważniejszych przesłanek konstrukcyjnych tej kondykcji 
w postaci porozumienia co do podstawy prawnej świadczenia, jego jurydycznego charakteru, treści, funkcji i celu.

Porozumienie to nie jest czynnością prawną, nie wynikają zatem $\mathrm{z}$ niego roszczenia (zaskarżalne zobowiązania), nawet gdy odnosi się do przyszłego zachowania oczekiwanego od odbiorcy świadczenia. Kondykcja ta nie jest stosowana na gruncie zaskarżalnych zobowiązań umownych. Porozumienie wyznacza cel świadczenia i zarazem przyszłą podstawę prawną świadczenia, która urzeczywistni się, jeżeli cel świadczenia zostanie osiągnięty. Jeżeli cel świadczenia nie zostanie osiągnięty, podlega ono zwrotowi, gdyż nie uzyskało oczekiwanej podstawy prawnej. Porozumienie stanowi podstawę zatrzymania przez odbiorcę uzyskanego świadczenia, dopóki nie okaże się, czy cel świadczenia został osiągnięty. Zbyt wąskie jest często przytaczane w orzecznictwie i doktrynie ujęcie ograniczające cel świadczenia do niewymuszalnego świadczenia wzajemnego oczekiwanego od odbiorcy świadczenia, cel ten może być bowiem dowolnym, przyszłym dozwolonym stanem faktycznym. Cel świadczenia jest odróżniany od motywu, którym kierował się świadczący. Zamiar osiągnięcia celu świadczenia stanowi przy tym przyczynę sprawczą świadczenia, bez której świadczenie nie zostałoby w ogóle spełnione. W przeciwieństwie do motywu świadczenia cel jest zawsze znany odbiorcy świadczenia i przez niego aprobowany co najmniej w sposób dorozumiany.

\section{Mutual Agreement on the Legal Grounds for Performance as a Prerequisite of 'CONDictio ob Rem'}

\section{Summary}

The roots of the contemporary concept of performance for a specific purpose which has not been achieved, as regulated in Art. $410 \$ 2$ of the Polish Civil Code, go back to the Roman concept of condictio ob rem. In this paper I deal with one of the basic prerequisites of its application, an agreement between the parties concerned as to the legal grounds for performance, its juridical character, contents, function and purpose. 
This kind of agreement cannot be regarded as a legal transaction, it does not generate claims (enforceable obligations), even if it refers to the conduct expected of the recipient of the given performance. Condictio $o b$ rem cannot be applied in actionable claims on the grounds of a contract. In the condictio ob rem agreement, the parties determine the purpose of the performance and its prospective legal grounds, which will be applicable if and when the purpose of performance is achieved. If the purpose is not achieved, the giver may claim the restitution of his performance, because it has not met the predetermined legal grounds. The condictio ob rem agreement gives the grounds entitling the recipient to retain the performance until such time when it is clear whether or not the purpose has been achieved. The popular view in Polish case law and civil law doctrine that the purpose of condictio ob rem performance may refer only to an unenforceable mutual performance expected of the recipient is too narrow. In fact, the purpose may refer to any future licit event or state of affairs and should be distinguishable from the giver's motive. The giver's intention to accomplish the purpose of the performance should constitute the effective cause of his action, without which performance cannot be achieved. Unlike the giver's motive, the purpose must be known to and approved by the recipient, at least per facta concludentia.

Słowa kluczowe: bezpodstawne wzbogacenie; świadczenie nienależne; świadczenie w zamierzonym celu; condictio ob rem; porozumienie co do podstawy prawnej świadczenia.

Keywords: unjustified enrichment; undue performance; performance for an intended purpose; condictio ob rem; agreement as to the legal grounds for performance. 


\section{Literatura}

Caemmerer E., Bereicherung und unerlaubte Handlung, [w:] Festschrift für E. Rabel, I: Rechtsvergleichung und Internationales Privatrecht, Tübingen 1954, s. 333-401.

Dannemann G., The German Law of Unjustified Enrichment and Restitution. A Comparative Introduction, Oxford 2009.

Dubis W., [w:] Kodeks cywilny. Komentarz, red. E. GNiEwek, Warszawa 2016.

Golec K., Zerwanie nieformalnego związku jako przesłanka zwrotu świadczenia, «Monitor Prawniczy»10/2018, s. 537-546.

Golecki M., Synallagma. Filozoficzne podstawy odpowiedzialności kontraktowej w klasycznym prawie rzymskim, Toruń 2008.

Gramm H., [w:] Beck'sche Kurzkommentare, VII Palandt, Bürgerliches Gesetzbuch, München 2004.

Karaszewski G., [w:] Kodeks cywilny. Komentarz, red. J. Ciszewski, P. Nazaruk, «Lex» 2019.

KoŁAкоwsкi K., [w:] Kodeks cywilny. Komentarz, red. G. BienieK, «LexisNexis» 2011.

KupIscH B., Leistungskondiktion bei Zweckverfehlung - Teil 1, «Juristenzeitung» 1985, s. 101-109.

Ksıężak P., Bezpodstawne wzbogacenie. Art. 405-414 KC. Komentarz, Warszawa 2007.

KsıĘżaK P., [w:] Kodeks cywilny. Komentarz, red. K. OsajdA, «Legalis» 2020.

Lachner C.M., Die 'condictio ob rem'. Ein Beitrag zu Grundlagen und Anwendungsbereich des $\$ 812$ I 22 Alt. BGB, Würzburg 1996.

Larenz K., Canaris C.W., Lehrbuch des Schuldrechts, München 1994.

Lieb M., [w:] Münchener Kommentar zum Bürgerlichen Gesetzbuch, V: Schuldrecht, 3: Besonderer Teil, München 2007.

LieBs D., Bereicherungsanspruch wegen Misserfolgs und Wegfall der Geschäftsgrundlage, «uristenzeitung» 1978, s. 697-703.

LeNel O., Die Lehre von der Voraussetzung (in Hinblick auf den Entwurfeines bürgerlichen Gesetzbuches), "Archiv für die civilistische Praxis» 74/1889, s. 213-239.

Lenel O., Nochmals die Lehre von der Voraussetzung, "Archiv für die civilistische Praxis» 79/1892, s. 49-107.

ŁęTOWska E., Bezpodstawne wzbogacenie, Warszawa 2000.

MaKıєŁA D., Pacta sunt servanda - grocjuszowski koncept prawnonaturalnego ładu w społeczeństwie, [w:] Pacta sunt servanda - nierealny projekt czy gwarancja ładu społecznego, red. E. Kozerska, P. SAdowski, A. Szymański, Kraków 2015, s. 47 i n. 
Momberg URIBE R.A., The effect of change of circumstances on the binding force of contracts, Utrecht 2011, s. 23 i n.

Mosтowiк P., Bezpodstawne wzbogacenie, «Studia Prawa Prywatnego» 2.5/2007, s. $41-97$.

Mostowiк P., Bezpodstawne wzbogacenie, [w:] System Prawa Prywatnego, t. 6. Zobowiązania. Część ogólna, Warszawa 2009, s. 203-324.

Mugdan B., Die gesammten Materialen zum Bürgerlichen Gesetzbuch für das Deutsche Reich, II: Recht der Schuldverhältnisse, Berlin 1899.

Mularski K., Kodeks cywilny. Komentarz, red. M. Gutowski, «Legalis» 2019.

Müнl O., Hadding W., [w:] Soergel Kommentar zum Bürgerlichen Gesetzbuch, Band 5/1, Schuldrecht IV/1, Stuttgart 2007.

Ohanowicz A., Niesłuszne wzbogacenie, [w:] A. Ohanowicz, Wybór prac, red. A. Gulczyński, Warszawa 2007, s. 707-954.

Ohanowicz A., Bezpodstawne wzbogacenie, [w:] A. Ohanowicz, Wybór prac, red. A. GulczYŃski, Warszawa 2007, s. 961-978.

Pietrzy kowski K., [w:] Kodeks cywilny, red. K. Pietrzykowski, «Legalis» 2020. Reuter D., Martinek M., Ungerechtfertigte Bereicherung, Tübingen 1983.

Röthel A., Die Kondiktion wegen Zweckverfehlung, "Juristische Ausbildung» 12/2013, s. 1246-1252.

RzeteckA-Gil A., Kodeks cywilny. Komentarz. Zobowiązania - część ogólna, «Lex» 2011.

Schwarz F., Die Grundlage der, condictio' im klassischen römischen Recht, Münster-Köln 1952.

SERDA W., Nienależne świadczenie, Warszawa 1988.

SовсZук M., Świadczenie w zamierzonym celu, który nie został osiągnięty. Studium z prawa rzymskiego, Toruń 2012.

Sовсzук M., Rzymska koncepcja darowizny na wypadek śmierci w komentarzu Paulusa do lex Iulia et Papia (D.39.6.35.2-3), «Studia Iuridica Toruniensia» 10/2012, s. 50-71.

Sовсzук M., 'Condictio causa data causa non secuta' and development of the contractual system, «Krakowskie Studia z Historii Państwa i Prawa» 2/2018, s. $177-195$.

Sовсzук M., Rozliczenia między stronami związków partnerskich na podstawie przepisów o bezpodstawnym wzbogaceniu, «Kwartalnik Prawa Prywatnego» 2/2015, s. 381-408.

Soвсzук M., Donation in contemplation of death as an example of datio ob rem in Roman Law, «Studia Iuridica Toruniensia» 23/2018, s. 291-308. 
Sовсzук M., Problem wykładni „celu świadczenia” w rozumieniu art. $410 \$ 2$ polskiego kodeksu cywilnego: argumenty historyka prawa rzymskiego, "Miscellanea Historico-Iuridica» 2/2018, s. 215 i n.

Soкоєоwsкi T., [w:] Kodeks cywilny. Komentarz, red. A. KidyвA, «Lex» 2014.

SORGE C., ,Condictio ob rem' und Rückabwicklung gemeinschaftsbezogener Zuwendungen in nichtehelichen Lebensgemeinschaften, «Juristenzeitung»13/2011, s. 660-671.

Sorge C., Verpflichtungsfreier Vertrag als schuldrechtlicher Rechtsgrund. Das Rechtsgeschäft der, condictio ob rem' gemäß $\$ 812$ Abs. 1 S. 1 Alt. 2 BGB jenseits von Erfüllungszwang und Markttausch, Göttingen 2017.

Söllner A., Der Bereicherungsanspruch wegen Nichteintritts des mit einer Leistung bezweckten Erfolges (\$ 812 Abs. 1 S. 2, 2 Halbsatz BGB), «Archiv für die civilistische Praxis» 163/1963, s. 20-45.

SójKa-Zıelı́́sкa K., Wielkie kodyfikacje cywilne. Historia i współczesność, Warszawa 2009.

Szymańska A., Actio civilis in factum - actio praescriptis verbis $w$ responsach Labeona, «Studia Iuridica» 41/2003, s. 293-306.

Świrgoń-Sкок R., Pretorskie pacta conventa servabo jako rzymskie korzenie zasady pacta sunt servanda, [w:] Pacta sunt servanda - nierealny projekt czy gwarancja ładu społecznego, red. E. Kozerska, P. SAdowski, A. SZymański, Kraków 2015, s. 11-21.

Trzaskowski R., [w:] Kodeks cywilny. Komentarz, red. J. Gudowski, «LexisNexis» 2013.

WEBER M., Bereicherungsansprüche wegen enttäuschter Erwartung?, «Juristenzeitung» 1989, s. 25-30.

WelKer G., Bereicherungsausgleich wegen Zweckverfehlung? Kritisches zu $\$ 812$ Abs. 1 S. 2 2.Alt. BGB. Zugleich ein Beitrag zur Struktur der Leistungskondiktion, Berlin 1974.

Westermann H.P., Die causa im französischen und deutschen Zivilrecht, Berlin 1967.

Wieling H.J., Bereicherungsrecht, Berlin 2013.

Windscheid B., Die Lehre des römischen Rechts von der Voraussetzung, Düsseldorf 1850.

Windscheid B., Die Voraussetzung, «Archiv für die civilistische Praxis» 78/1892, s. 161-202.

Wojciechowski R., Bernhard Windscheid (1817-1892), «Kwartalnik Prawa Prywatnego» 18/2009, s. 593-619. 
Zimmermann R., The Law of Obligations. Roman Foundations of the Civilian Tradition, Cape Town-Wetton-Johannesburg 1990.

Zimmermann R., Roman-Durch jurisprudence and its Contribution to European Private Law, «Tulane Law Review» 66.6/1992, s. 1686-1721. 